Biogeosciences Discuss., 7, 5953-5995, 2010

www.biogeosciences-discuss.net/7/5953/2010/

doi:10.5194/bgd-7-5953-2010

(C) Author(s) 2010. CC Attribution 3.0 License.

\title{
Impact of nutrient starvation on the biochemical composition of the marine diatom Thalassiosira weissflogii: from the whole cell to the frustule fraction
}

C. Soler ${ }^{1}$, P. Claquin ${ }^{2}$, M. Goutx ${ }^{3}$, O. Ragueneau ${ }^{1}$, and B. Moriceau ${ }^{1}$

${ }^{1}$ Laboratoire des Sciences de l'Environnement Marin, UMR 6539, Institut Universitaire Européen de la Mer, Place Nicolas Copernic, 29280 Plouzané, France

${ }^{2}$ Laboratoire de Physiologie et d'Ecophysiologie des Mollusques Marins, UMR 100 IFREMER, Université de Caen Basse-Normandie, Esplanade de la paix BP 5186, 14032 Caen Cedex, France

${ }^{3}$ Laboratoire Microbiologie, Géochimie et Ecologie Marines, UMR 6117 CNRS - INSU, Centre d'Océanologie de Marseille, Campus de Luminy, 13288 Marseille, Cedex 9, France

Received: 10 July 2010 - Accepted: 27 July 2010 - Published: 13 August 2010 Correspondence to: C. Soler (charlotte.soler@univ-brest.fr) Published by Copernicus Publications on behalf of the European Geosciences Union.
Impact of nutrient availability on frustule composition

C. Soler et al.

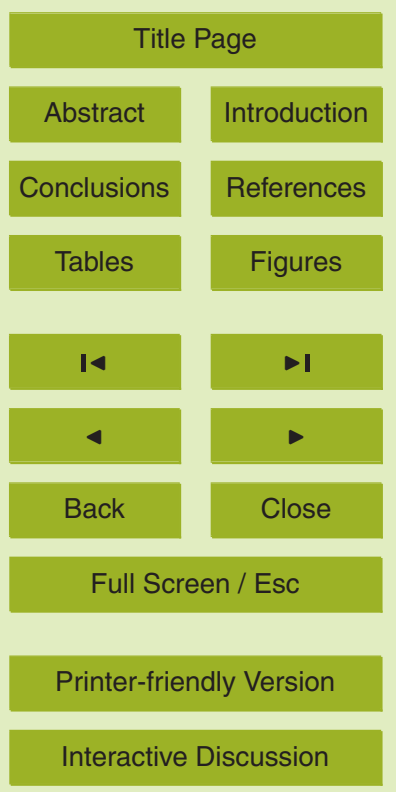




\section{Abstract}

Interactions between carbon and silica in the diatom frustule play an important role in carbon export through their impact on diatom remineralization (carbon degradation and biogenic silica dissolution). To ameliorate model prediction of the fate of Si and organic matter during sedimentation, there is a need to first understand the origin and nature of Si-OC interactions, their impact on diatom remineralization and their variability with environmental conditions. In this study we focus on the impact of nutrient starvations on the formation and nature of these interactions in an ubiquitous diatom, Thalassiosira weissflogii. Fluorescence reveals the strong impact of all starvations on diatom metabolism while Fourier transformed infrared (FTIR) spectroscopy clearly showed that starvations altered the composition of the different diatom fractions. The relative compositions of whole cells were almost not impacted by starvations except $\mathrm{Si}(\mathrm{OH})_{4}$ starvation that slightly increased proteins relative contribution while decreasing carbohydrate. Starvation impacts became obvious looking at the composition of the different part of the diatom. The relative biochemical composition of the organic coating, protecting the frustule from the environment, was strongly affected by starvation. Under nitrate starvation, carbohydrate contribution increased while protein contribution decreased. Inversely, phosphate starvation increased the proportion of proteins and decreased carbohydrates contribution. Starvations also modified the different frustule phases. $\mathrm{bSiO}_{2}$ contribution decreased in the less reactive phase under silicate and phosphate starvation whereas nitrate starvation rather increased carbohydrate and protein pools. Phosphate starvation also led to an important shift of dominance among protein groups between amide I and amide II which compounds are suspected to play a key role in the frustule synthesis and architecture. Nutrient starvations affected the relative biochemical composition of diatom frustule fractions and organic coating which could imply a strong impact on frustule structure and architecture but also on frustule mechanical and chemical resistance.
BGD

7, 5953-5995, 2010

\section{Impact of nutrient availability on frustule composition}

C. Soler et al.

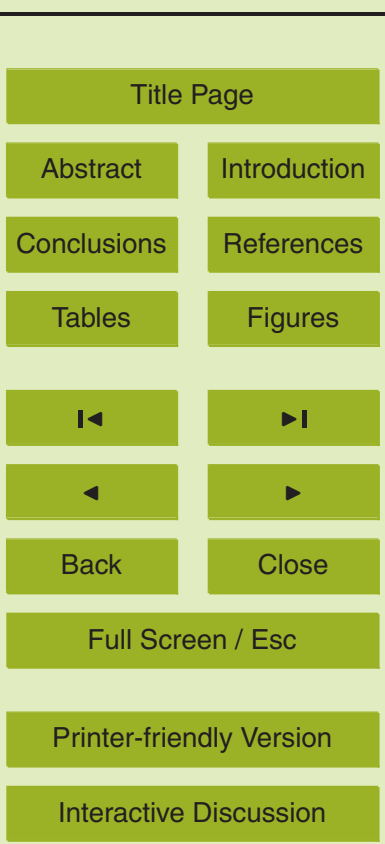




\section{Introduction}

Spatial and temporal occurrence and the species composition of phytoplankton efflorescence are controlled by environmental conditions such as nutrient or light availability, which affect phytoplankton metabolism. Diatoms form a phytoplanktonic group that 5 can be distinguished from others by their cell wall, called frustule, which is composed of biogenic silica $\left(\mathrm{bSiO}_{2}\right)$ derived from polymerization of silicic acid, $\mathrm{Si}(\mathrm{OH})_{4} \cdot \mathrm{Si}(\mathrm{OH})_{4}$ concentrations can consequently limit diatom growth during bloom in coastal waters (Ragueneau et al., 1994; Nelson and Dortch, 1996) and also in the open ocean (Dugdale et al., 1995; Brzezinski and Nelson, 1996). The availability of other macronutrients could also limit diatom growth and affect diatom physiology because of the metabolic requirements of the organisms. Nitrogen and phosphorus are, together with carbon, the basic elements used in the synthesis of organic molecules through photosynthesis. Moreover, phosphorus also plays a key role in energetic transfers (ATP) and is essential in DNA molecules and cellular membrane structure. In this study, we aim to differentiate nutrient starvation from nutrient limitation. Nutrient limitation is very common in the open ocean where phytoplankton cells have to adapt to nutrient concentration levels that may be far from their optimum growth condition (represented by their affinity to the different nutrients). Nutrient starvation mainly occurs at the end of a bloom when the concentration of the most limiting nutrient becomes close to 0 . In this second situation, phytoplankton cells are suddenly subjected to nutrient stress while they are growing in almost optimum conditions. Few studies have reported on the impact of nutrient starvation on diatom photosynthesis (Lippemeier et al., 2001; De La Rocha and Passow, 2004), whereas the effects of nutrient limitation have been widely observed (Reynolds et al., 1997; Beardall et al., 2001; Lippemeier et al., 1999; Berges et al., 1996; Osborne 25 and Geider, 1986). Macromolecules (carbohydrates, amino acids, and lipids) are synthesized from carbon skeletons of sugars produced during photosynthesis. Production of main biochemical pools seems to be correlated with the different growth phases. For example, protein synthesis occurs in the initial exponential growth phase, whereas the
BGD

7, 5953-5995, 2010

\section{Impact of nutrient availability on frustule composition}

C. Soler et al.

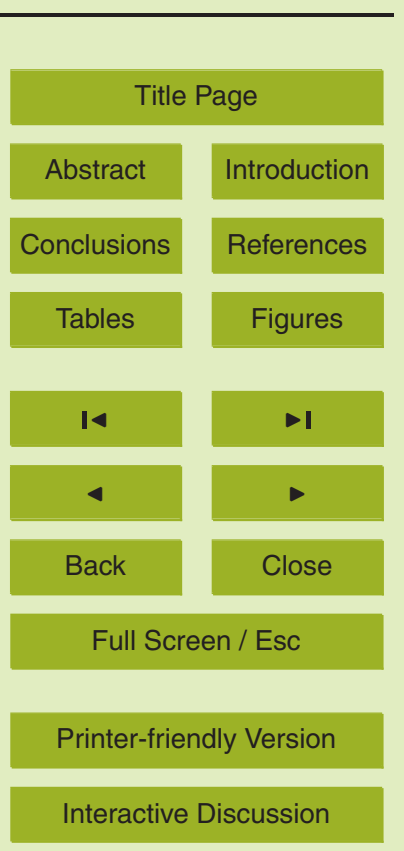

Interactive Discussion 
protein pool is reduced in the stationary and senescent phases when nutrient availability decreases (Mayzaud et al., 1990). Although $\mathrm{NO}_{3}, \mathrm{Si}(\mathrm{OH})_{4}$, and $\mathrm{PO}_{4}$ stresses all induce a decrease of photosynthetic activity, the impact on biochemical pools will depend on the limiting nutrient. $\mathrm{NO}_{3}$ depletion mainly affects the lipid content of diatoms 5 (Shifrin and Chisholm, 1981), whereas depletion of both $\mathrm{NO}_{3}$ and $\mathrm{PO}_{4}$ reduces the protein pool while increasing carbohydrate synthesis (Guerrini et al., 2000). $\mathrm{Si}(\mathrm{OH})_{4}$ starvation is not supposed to impact diatom photosynthesis as the energy required for silicification is not provided by the photosynthesis (Sullivan, 1976) but by aerobic respiration (Lewin, 1955). However, Lippemeier et al. (1999) clearly showed that $\mathrm{Si}(\mathrm{OH})_{4}$ 10 metabolism has strong influences on the photosynthetic parameters of diatom cells. The impact of nutrient starvation on the biochemical composition of diatom cells if not well known can modify the quality of diatom organic matter; indeed, many studies have shown an impact of nutrient conditions on the phytoplankton nutritional properties leading to a decrease of the reproductive success of copepods (Koski et al., 1998; Tang and 15 Dam, 2001; Koski et al., 2006). Understanding the biochemical changes in diatoms is essential because of their potential impact on the food web. Diatoms play a key role in marine primary production, and account for $40 \%$ of the total primary production in the marine ecosystem (Nelson et al., 1995; Smetacek, 1999; Tréguer and Pondaven, 2000). Because their frustules can function as ballasts, and because they can enter large particles such as aggregates or fecal pellets, diatoms also tend to dominate the export of carbon (Buesseler, 1998; Ragueneau et al., 2006). Remineralization of $\mathrm{bSiO}_{2}$ and diatom organic matter will occur in the water column and is controlled by many factors, such as zooplankton grazing (Jansen, 2008) and bacterial degradation (Bidle and Azam, 1999). Moreover, while the contribution of the biochemical pool in diatoms is affected by environmental conditions, the effects of growth conditions on the organic matter pool in the frustule are still unknown. Changes in the frustule composition may affect the quantity and quality of the carbon export from the surface waters to the deep ocean as well as the remineralization rate of diatoms. Several studies suggested that the frustule is composed of different phases (Gallinari et al., 2002; Moriceau et al.,
BGD

$7,5953-5995,2010$

\section{Impact of nutrient availability on frustule composition}

C. Soler et al.

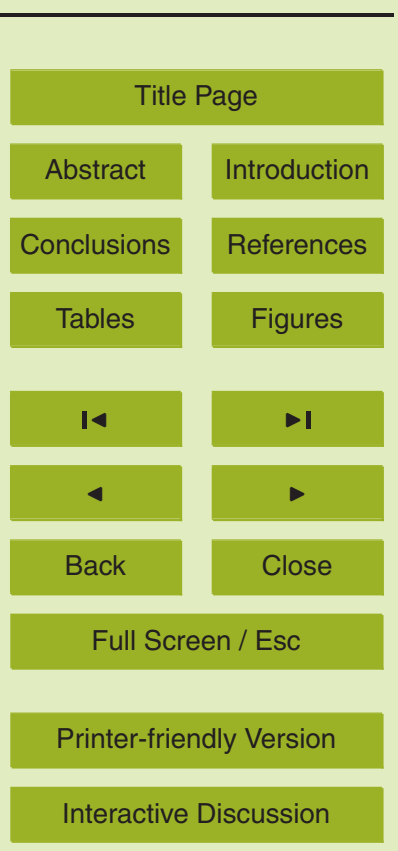


2009) containing a high proportion of organic matter (Soler et al., 2010). First, the organic coating around $\mathrm{bSiO}_{2}$, which protects the frustule from dissolution (Bidle and Azam, 1999), is rich in proteins and carbohydrates (Hoagland et al., 1993). Then, 2 different phases were distinguished inside the frustule; the most reactive phase is par5 ticularly rich in $\mathrm{bSiO}_{2}$ and carbohydrates, and also contains proteins and lipids; the other phase is less reactive and is essentially formed by proteins (Soler et al., 2010).

This study attempts to better understand the impact of nutrient starvation on the composition of diatom cells and their frustule, and the effects of these modifications on the quality of the export of organic matter. Laboratory experiments, combining struc10 tural and physiological analyses, were undertaken using a monospecific culture of the common diatom Thalassiosira weissflogii (Bacillariophyceae) grown in different nutrient stress conditions. Photosynthetic parameters were measured throughout the experiments with a pulse amplitude modulated (PAM) fluorometer. These factors indicated the duration of starvation required to have a significant effect on diatom physiology. 15 When the starvation state was reached, the relative biochemical composition of diatom cells and frustule phases was investigated with Fourier transform infrared (FTIR) spectroscopy.

\section{Material and methods}

\subsection{Culture and samplings}

20 The marine diatom T. weissflogii (strain CCMP 1049) was grown at $18^{\circ} \mathrm{C}\left( \pm 1^{\circ} \mathrm{C}\right.$ ) under a light/dark cycle (16h:08 h) in f/2 medium (Guillard and Ryther, 1962) prepared from artificial seawater (Harrison et al., 1980) under a photon flux density of $180 \mu \mathrm{mol}$ photons $\mathrm{m}^{-2} \mathrm{~s}^{-1}$. Batch culturing of phytoplanktons is considered to simulate a bloom with 3 major growth phases: exponential, plateau, and senescent (Fogg

25 and Thake, 1987). The initial culture of $T$. weissflogii in $\mathrm{f} / 2$ medium was treated with a mix of antibiotics (penicillin G, streptomycin, and gentamycin) (Guillard, 2005). The
BGD

7, 5953-5995, 2010

\section{Impact of nutrient availability on frustule composition}

C. Soler et al.

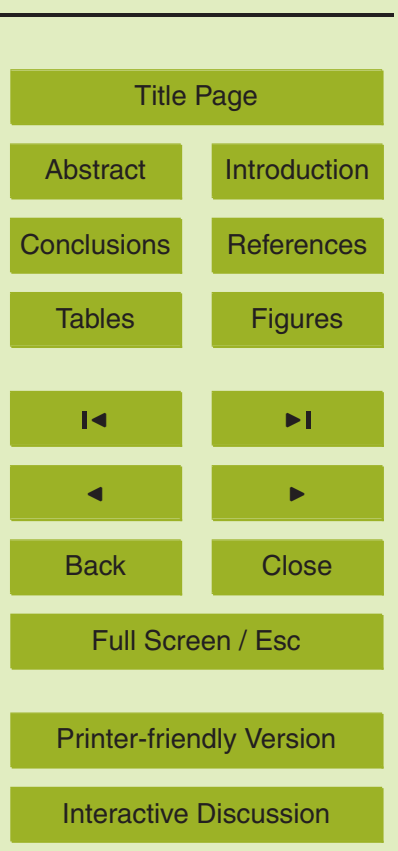


absence of bacteria was checked before placing the inoculum on ZoBell agar plants (ZoBell, 1941). $\mathrm{NO}_{3}, \mathrm{Si}(\mathrm{OH})_{4}$, and $\mathrm{PO}_{4}$ starvation experiments were undertaken in 1-L batch culture, in duplicates, by switching the medium supply from normal f/2 to $\mathrm{NO}_{3}{ }^{-}$, $\mathrm{Si}(\mathrm{OH})_{4^{-}}$, or $\mathrm{PO}_{4}$-free $\mathrm{f} / 2$ medium. Axenic batch cultures were prepared by using low5 cell-density inoculums to reach an initial cell concentration around $5 \times 10^{3}$ cells $\mathrm{mL}^{-1}$. One liter of a culture grown in complete $f / 2$ medium in exponential phase was centrifuged, and the pellet was divided into 8 equal fractions, 1 for each batch ( 2 batches for the control in complete $f / 2$ medium and 2 batches for each starvation). Before inoculation in the starved medium, each pellet was rinsed 3 times with the corresponding 10 medium. All cultures were manually mixed by gentle swirling several times per day to keep cells in suspension. Samplings for biochemical fractionation were always done at the end of the exponential growing phase during the stationary when the starvation appeared. Cells were collected by centrifugation ( $3220 \mathrm{~g}, 15 \mathrm{~min}$ ) and an aliquot of the resulting pellet was treated to isolate the frustule while another was directly analyzed 15 using FTIR spectroscopy.

\subsection{Fractionation of the diatoms}

Diatoms grown under the 4 different conditions were centrifuged and divided into 4 different fractions (Fig. 1), 1) the whole cell; 2) the total frustule, composed of the frustule and its organic coating; 3 ) the cleaned frustule, which contained the 2 different 20 phases but without organic coating; and 4) the less reactive phase of the frustule, which reflects the composition of the less reactive phase of the frustule.

Whole-cell pellets were heated at $70^{\circ} \mathrm{C}$ and sonicated for $120 \mathrm{~s}$ at $75 \mathrm{~W}$ to induce mechanical rupture of frustule. The sample was centrifuged at $3000 \mathrm{~g}$ for $40 \mathrm{~min}$, and the supernatant was separated from the pellet (Fig. 1). Then, the pellet was chemically 25 treated to separate the pigments, carbohydrates, and sugar building cellular membranes from the frustule using a methanol/chloroform/water (3:5:3) extraction method adapted from Granum and Myklestad $(1999,2001)$. The sample was mixed well, and phase separation was accelerated by incubation for $10 \mathrm{~min}$ at $4{ }^{\circ} \mathrm{C}$. During this extrac5958

\section{BGD}

7, 5953-5995, 2010

\section{Impact of nutrient availability on frustule composition}

C. Soler et al.

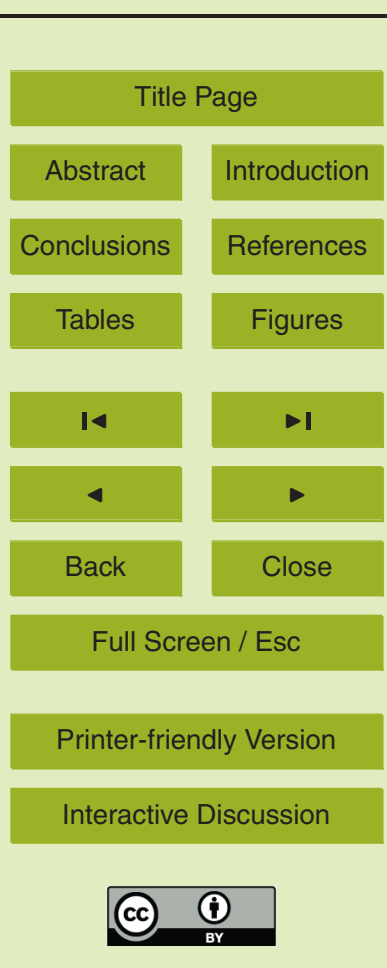


tion, the compounds were separated according to their polarity.

Three phases were obtained: 2 liquid phases, namely, a lower chloroform phase and an upper methanol phase, and a solid phase between the 2 liquid phases, forming an interface, which is named TF (total frustule) hereafter. An aliquot of the solid 5 fraction was heated in an electric bunsen burner in the presence of concentrated nitric acid solution $\left(\mathrm{HNO}_{3}\right)$ to eliminate most of the organic matter linked to $\mathrm{bSiO}_{2}$; this fraction is named the acid frustule washed (FAW) fraction. The second treatment included hydroxide extractions using a $1 \mathrm{M} \mathrm{NaOH}$ bath at $95^{\circ} \mathrm{C}$ for $1 \mathrm{~h}$ to dissolve $\mathrm{bSiO}_{2}$ (Ragueneau and Treguer, 1994), and the resulting fraction is called the basic frustule washed 10 (FBW) fraction. All samples were rinsed 3 times with distilled water to eliminate traces of acid and base before FTIR analysis.

\subsection{Photosynthetic parameters}

Photosynthetic parameters were quantified by measuring variable fluorescence. The maximum energy conversion efficiency, or quantum efficiency of photosystem II charge 15 separation $\left(F_{\mathrm{v}} / F_{\mathrm{m}}\right)$, was measured using WATER/B-PAM (Walz, Effeltrich, Germany) (Schreiber et al., 1986). After a dark adaptation of $10 \mathrm{~min}$, a $3 \mathrm{~mL}$ subsample was placed in a darkened measuring chamber. The sample was excited by a weak blue light $\left(1 \mu \mathrm{mol} \mathrm{m}{ }^{-2} \mathrm{~s}^{-1}, 470 \mathrm{~nm}\right.$, frequency $\left.0.6 \mathrm{kHz}\right)$, and fluorescence was detected at wavelengths above $695 \mathrm{~nm}$. The blank was analyzed on a filtered medium $(0.2 \mu \mathrm{m}$ 20 polycarbonate membrane filter). The quantum efficiency of photosystem II $\left(F_{\mathrm{v}} / F_{\mathrm{m}}\right)$ was calculated by:

$\frac{F_{\mathrm{v}}}{F_{\mathrm{m}}}=\frac{\left(F_{\mathrm{m}}-F_{0}\right)}{F_{\mathrm{m}}} \quad$ (Genty et al., 1989)

where $F_{0}$ is the minimal fluorescence and $F_{\mathrm{m}}$ is the maximum fluorescence (during a saturating light pulse, $0.6 \mathrm{~s}, 470 \mathrm{~nm}, 1700 \mu \mathrm{mol} \mathrm{m} \mathrm{m}^{-2} \mathrm{~s}^{-1}$ ) of a dark-adapted sample.

$25 \quad$ A light curve relating the photosynthetic electron transport rate (ETR) to the irradiance $(E)$ was performed. The samples were exposed to 9 different irradiances $(E)$ from 5959
BGD

$7,5953-5995,2010$

Impact of nutrient availability on frustule composition

C. Soler et al.

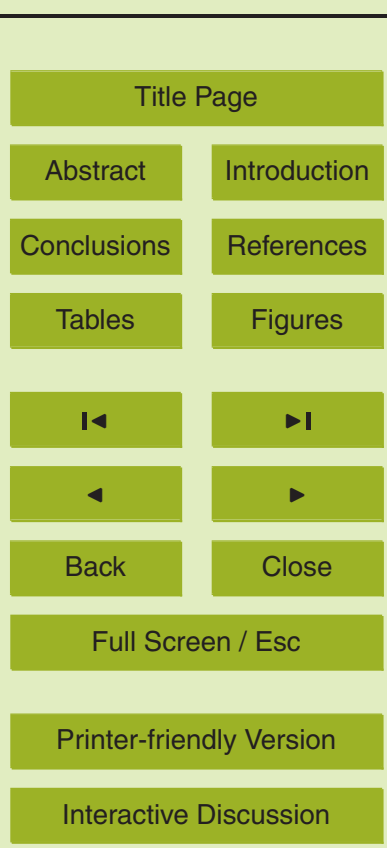

Interactive Discussion 
0 to $1500 \mu \mathrm{mol}$ photon $\mathrm{m}^{-2} \mathrm{~s}^{-1}$ for $60 \mathrm{~s}$ each (Perkins et al., 2006). Light intensity was calibrated by using a microspherical quantum sensor (US-SQS/L Walz, Effeltrich, Germany). The steady-state fluorescence $\left(F_{\mathrm{s}}\right)$ and the maximal fluorescence $\left(F_{\mathrm{m}}^{\prime}\right)$ were measured. According to Genty et al. (1989), the effective quantum efficiency of photo5 system II in actinic irradiance was calculated as:

$\frac{\Delta F}{F_{\mathrm{m}}^{\prime}}=\frac{\left(F_{\mathrm{m}}^{\prime}-F_{\mathrm{s}}\right)}{F_{\mathrm{m}}^{\prime}}$

Cultures were maintained until the $F_{\mathrm{v}} / F_{\mathrm{m}}$ value was more than 0.5 . Diatom growth lasted 12 days for the $\mathrm{Si}(\mathrm{OH})_{4}$ and the $\mathrm{NO}_{3}$ starvations and only 7 days for $\mathrm{PO}_{4}$ starvation. Control culture was stopped after 6 days to avoid any nutrient limitation. $\Delta F / F_{\mathrm{m}}^{\prime}$ can be used to calculate the ETR (in $\mu \mathrm{mol} \mathrm{e}^{-1}\left(\mathrm{mg} \mathrm{Chl}^{-a}\right)^{-1} \mathrm{~s}^{-1}$ ) as of a single active photosystem II unit (Genty et al., 1989; Hofstraat et al., 1994) :

$\mathrm{ETR}=\frac{\Delta F}{F_{\mathrm{m}}^{\prime}} \times E \times a^{*} \mathrm{PSII}$

where $a^{*} \mathrm{PSII}$ is the optical cross-section of photosystem II. As we could not measure $a^{*}$ PSII, we calculated ETR per unit chlorophyll by using the calculation method proposed by Johnsen and Sakshaug (2007). We considered that the fraction of absorbed quanta to photosystem II between 400 and $700 \mathrm{~nm}$ is 0.74 . ETR ( $\mu \mathrm{mole}^{-1}$ (mg Chla) ${ }^{-1} \mathrm{~s}^{-1}$ ) was then calculated as follows:

$\mathrm{ETR}=\frac{\Delta F}{F_{\mathrm{m}}^{\prime}} \times E \times a^{*} \times 0.74$

where $a^{*}$ is the chlorophyll-specific absorption cross-section $\left(\mathrm{m}^{2} \mathrm{mg}^{-1} \mathrm{Chl}-\mathrm{a}^{-1}\right)$ calcu20 lated from the chlorophyll concentration and in vivo absorption (Dubinsky et al., 1986).

P-E curves were obtained with the fitting model proposed by Eilers and Peeters (1988):

$$
\mathrm{ETR}=\frac{E}{a E^{2}+b E+c}
$$

BGD

7, 5953-5995, 2010

\section{Impact of nutrient} availability on

frustule composition

C. Soler et al.

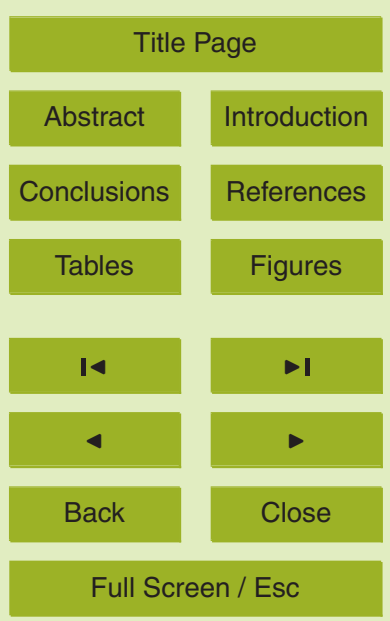

Printer-friendly Version

Interactive Discussion 
with

$$
\begin{array}{ll}
\alpha=\frac{1}{c} \quad \omega=\frac{b}{\sqrt{a c}} \\
\\
\text { ETRmax }=\left[b+2 \times(a c)^{0.5}\right]^{-1}
\end{array}
$$

BGD

where $\alpha$, the initial slope of the P-E curve, represents the maximum light utilization coefficient and $\omega$ represents the photoinhibition parameter. According to the Eilers and Peeters (1988) model, a low value of $\omega$ indicates high photoinhibition.

\subsection{Fourier transform infrared spectroscopy}

\subsubsection{Sample preparation}

Solid samples were dried with potassium bromide $(\mathrm{KBr})$ and milled to obtain a fine powder. This powder was compressed into a thin pellet before being placed in a desiccator (Schott) under 1 bar pressure for $30 \mathrm{~min}$. The sample was then introduced into a spectrometer for spectral acquisition. $\mathrm{KBr}$ was used as a matrix for solid samples because of its range of transparency to infrared radiation; $100 \mathrm{mg}$ of $\mathrm{KBr}$ was weighed for every $8 \mathrm{mg}$ of sample.

\subsubsection{FTIR standards}

15 Diatomite is a siliceous sedimentary rock resulting from the accumulation in oceans or fresh waters of the amorphous silica (opal, $\mathrm{SiO}_{2} \mathrm{CnH}_{2} \mathrm{O}$ ) from cell walls of dead diatoms over geological time scales. Diatomite is composed of $80-90 \%$ (sometimes $95 \%$ ) silica $\left(\mathrm{SiO}_{2}\right)$ plus alumina (2-4\% attributed mostly to clay minerals) and hematite $(0.5-2 \%)$ (Antonides, 1998). Since diatomite is mainly composed of $\mathrm{bSiO}_{2}$, it was used as the $\mathrm{bSiO}_{2}$ standard.

\section{Impact of nutrient availability on frustule composition}

C. Soler et al.

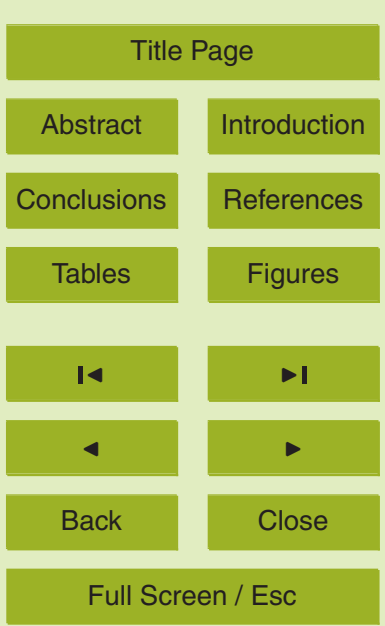

Printer-friendly Version

Interactive Discussion 


\subsubsection{Spectral acquisition}

Spectra were collected on an FTIR spectrometer (Tensor 27 Bruker) equipped with a $\mathrm{KBr}$ beam splitter and fitted with a deuterated triglycine sulfate detector. The Bruker system was controlled by a computer using OPUS software version 5.5. The ab5 sorbance spectra were collected between 3600 and $600 \mathrm{~cm}^{-1}$ at a spectral resolution of $4 \mathrm{~cm}^{-1}$ with 10 scans added and averaged. As the frequency range from 800 to $2200 \mathrm{~cm}^{-1}$ included almost all organic matter bands (amides, proteins, lipids, and carbohydrates) and silica bands, the other part of the FTIR spectrum was not shown. Differences between spectra due to baseline shifts were reduced with a baseline correction using the "rubber band" algorithm of 200 baseline points.

\subsubsection{Band assignments}

Bands were assigned based on the band assignments in previous studies by Coates (2000), Giordano et al. (2001), and Benning et al. (2004). We estimated the relative contribution of each pool to the global biochemical composition by comparing 15 their deconvolved spectra (OPUS software, Fourier self-deconvolution, noise reduction 0.5). The contribution of the different FTIR peaks to the global biochemical composition was estimated by integrating the surface area of each band.

\subsubsection{Cluster analysis}

Among the various mathematical methods applied for classification in biology and medicine, cluster analysis is one of the simplest and most rapid procedures. In our study, this technique was used to validate the FTIR method for the analysis of diatom frustule fractions. Cluster analysis was performed by using OPUS software with standard making distance matrix and Ward's algorithm dendogram.

BGD

$7,5953-5995,2010$

Impact of nutrient availability on frustule composition

C. Soler et al.

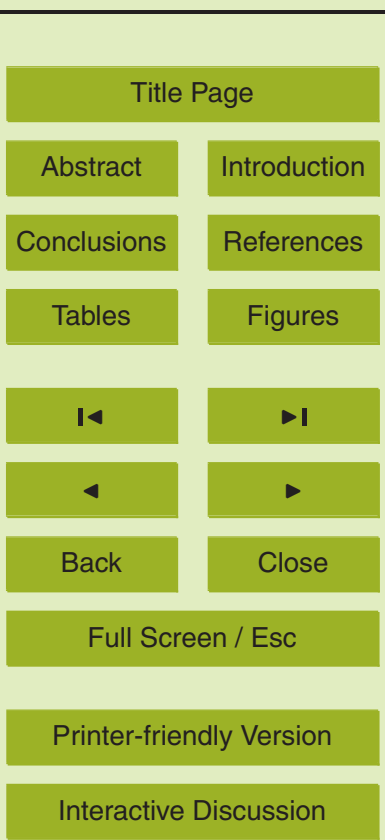




\section{Results}

\subsection{Diatom physiology}

BGD

Comparison of PE curves (Fig. 2) showed that starvations strongly impact photosynthesis since the first day but not with the same intensity. Under $\mathrm{PO}_{4}$ starvation,

5 cells were not able to maintain photosynthesis. Immediately after the start of the experiment, ETRmax dropped to less than $0.17 \mu \mathrm{mol} \mathrm{e}^{-1}(\mathrm{mg} \mathrm{Chl}-\mathrm{a})^{-1} \mathrm{~s}^{-1}$ and after 7 days, when $F_{\mathrm{v}} / F_{\mathrm{m}}$ was around 0.3 . Photosynthesis was strongly affected by an ETRmax below $0.02 \mu \mathrm{mol} \mathrm{e}^{-1}(\mathrm{mg} \mathrm{Chl}-a)^{-1} \mathrm{~s}^{-1}$ and a photosynthesis efficiency $(\alpha)$ below

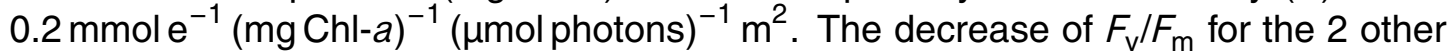
10 starvations was observed after 12 days $\left(0.50\right.$ and 0.44 for $\mathrm{NO}_{3}$ and $\mathrm{Si}(\mathrm{OH})_{4}$ starvations, respectively). ETRmax decreased to 0.95 and $0.58 \mu \mathrm{mol} \mathrm{e}^{-1}(\mathrm{mg} \mathrm{Chl}-a)^{-1} \mathrm{~s}^{-1}$, and $\alpha$ was around 1.0 and $0.7 \mathrm{mmol} \mathrm{e}^{-1}(\mathrm{mg} \mathrm{Chl}-a)^{-1}$ ( $\mu$ mol photons $)^{-1} \mathrm{~m}^{2}$ for $\mathrm{NO}_{3}$ - and $\mathrm{SiOH}_{4}$-starved cells, respectively. The decrease in the $\mathrm{P}-\mathrm{E}$ curve of $\mathrm{NO}_{3}$-starved cells after $1000 \mu \mathrm{mol}$ photons $\mathrm{m}^{-2}$, corresponding to photoinhibition (Fig. 2: day 7; Table 1: $\left.15 \omega=2.63 .10^{-9} \mathrm{mmol} \mathrm{e}^{-1}(\mathrm{mg} \mathrm{Chl}-a)^{-1}(\mu \mathrm{mol} \text { photons })^{-1} \mathrm{~m}^{2}\right)$, is notable. The impact of $\mathrm{PO}_{4}$ starvation was much more severe than those of $\mathrm{Si}(\mathrm{OH})_{4}$ and $\mathrm{NO}_{3}$ starvations.

Monitoring of physiological parameters was used as an index to determine the time necessary to observe an impact of each starvation on the physiological status of the culture. Modifications of photosynthetic parameters, and more generally of the physiological capacities resulting from nutrient depletions, correspond to a redistribution of the biochemical pools of diatoms. Such variations were observed by FTIR analyses on diatom whole cells and on the different frustule phases.

Figure 3 shows FTIR spectra of whole diatoms grown under various nutrient starvations (control, and $\mathrm{NO}_{3}, \mathrm{Si}(\mathrm{OH})_{4}$, and $\mathrm{PO}_{4}$ starvation media). The vibration bands were shown by footnotes corresponding to the main biochemical pools. Comparison of FTIR spectra (Fig. 3) revealed important differences between the 4 growth conditions. Diatom whole cell spectra were dominated by organic matter compounds (around $88 \%$

\section{Impact of nutrient availability on frustule composition}

C. Soler et al.

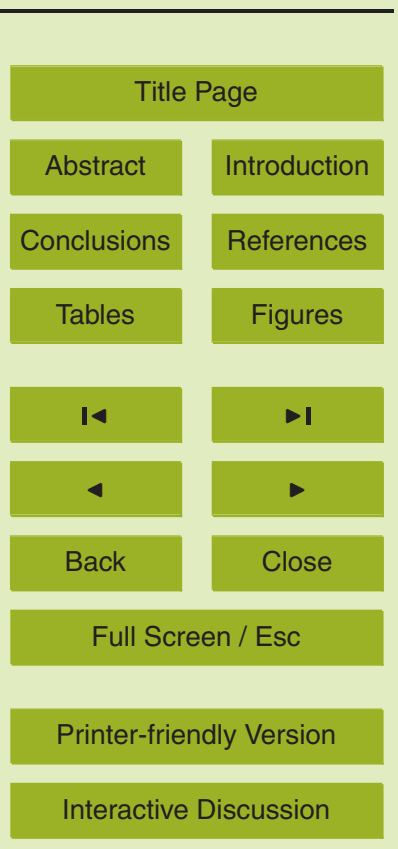


of the global composition) and more precisely by proteins (Fig. 4a-d), represented by bands 2 to 4 , located between 1700 and $1300 \mathrm{~cm}^{-1}$. Band 2 was attributed to $\mathrm{C}=\mathrm{O}$ and $\mathrm{N}-\mathrm{H}$ stretching and to $\mathrm{C}-\mathrm{N}$ bending vibration of primary amide compounds (amide I) associated with proteins. Band 3 was assigned to secondary amide (amide II) $5 \mathrm{~N}-\mathrm{H}$ bending and $\mathrm{C}-\mathrm{N}$ stretching. Amine vibrations were observed between 1470 and $1300 \mathrm{~cm}^{-1}$ (band 4). This protein pool is highly affected by nutrient starvations, especially $\mathrm{Si}(\mathrm{OH})_{4}$ and $\mathrm{PO}_{4}$ starvations.

The relative contribution of main biochemical pools in whole-cell fractions are presented on Fig. 4. The contribution of proteins was around $42 \%$ for control (Fig. 4a), $10 \mathrm{NO}_{3}$-starved cells (Fig. 4b), and $\mathrm{PO}_{4}$-starved cells (Fig. 4d), whereas protein contribution reached $49 \%$ for $\mathrm{Si}(\mathrm{OH})_{4}$-starved cells (Fig. 4c). Among proteins, the function amide I dominated the pool, with a contribution of $22 \%$ for control, $23 \%$ for $\mathrm{NO}_{3}$-starved cells, and $28 \%$ for $\mathrm{Si}(\mathrm{OH})_{4}$-starved cells (Fig. $4 \mathrm{a}$ ). $\mathrm{PO}_{4}$-starved cells contained approximately as many amines as amide I (Fig. 4d: 15\%). The ratio between amide I and 15 amide II was around 3 for the control and $\mathrm{NO}_{3}$-starved cells, 3.5 for $\mathrm{Si}(\mathrm{OH})_{4}$-starved cells, and below 1.5 for $\mathrm{PO}_{4}$-starved cells.

The second major group of bands was detected between 1300 and $900 \mathrm{~cm}^{-1}$ (Fig. 3; bands 5 and 6), and corresponded to carbohydrates and biogenic silica vibrations. Spectra deconvolution allows to differentiate 2 bands observed in the same spectral 20 area. Carbohydrates, assigned to peaks located between 1250 and $1000 \mathrm{~cm}^{-1}$ corresponding to $\mathrm{C}-\mathrm{O}$ stretching vibration, appeared as the second major constituent of whole diatom cells. The shape of this band varied greatly between spectra of the four growth conditions. $\mathrm{PO}_{4}$-starved cells were characterized by a high absorbance in the carbohydrate vibration area $\left(1100-1250 \mathrm{~cm}^{-1}\right)$, with 5 peaks clearly dissociated (Fig. 3, 25 band 5: $1220,1210,1158,1106$, and $\left.1085 \mathrm{~cm}^{-1}\right)$; on the other starvation spectra, only 3 peaks were observed (Fig. 3, band 5: 1220, 1158, and $1085 \mathrm{~cm}^{-1}$ ). Carbohydrate contribution reached $36 \%$ of the global composition for control and $\mathrm{NO}_{3}$-starved cells, and $34 \%$ for $\mathrm{PO}_{4}$-starved cells (Fig. 4a,b,d, respectively). In comparison, the proportion of the carbohydrate pool in $\mathrm{Si}(\mathrm{OH})_{4}$-starved cells was only $30 \%$ (Fig. $4 \mathrm{c}$ ).
BGD

7, 5953-5995, 2010

\section{Impact of nutrient availability on frustule composition}

C. Soler et al.

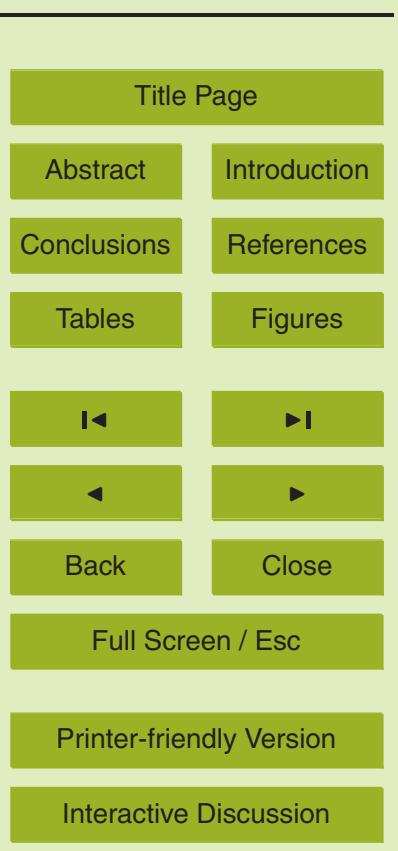


With regard to biogenic silica contribution, free $\mathrm{Si}-\mathrm{O}$ and bound $\mathrm{Si}-\mathrm{OH}$ groups were observed at around $900 \mathrm{~cm}^{-1}$ and inter-tetrahedral Si-O-Si bonds at around $800 \mathrm{~cm}^{-1}$ (Fig. 3: band 6). The principal bond vibration of biogenic silica was observed between 1150 and $950 \mathrm{~cm}^{-1}$ and was assigned to the bending vibration of $\mathrm{SiO}_{4}$ tetrahedron.

5 Peaks located in these 3 areas were added to calculate the relative contribution of biogenic silica. This contribution was estimated to be around $12 \%$ of the whole cells for all growth conditions, except for $\mathrm{Si}(\mathrm{OH})_{4}$ starvation that showed a $\mathrm{bSiO}_{2}$ contribution of around $10 \%$ (Fig. 4).

Lipids were also visible and were characterized by 2 bands; the first band between 10 lipid contribution) and the other band around $1740 \mathrm{~cm}^{-1}$ (Fig. 3: band 1). Band 2
was clearly visible for $\mathrm{PO}_{4}$ and $\mathrm{Si}(\mathrm{OH})_{4}$ starvations (Fig. 3); however, proportionally, lipid contribution was not significantly higher in cells grown under these 2 conditions (Fig. 4a-d). In this study, the contribution of lipid pool to the global composition of 15 T. weissflogii was near $10 \%$.

Nutrient stresses obviously lead to important variations in biochemical pools of diatom cells. This study aims to identify where these variations are located in the cell. FTIR analyses showed the various modifications in the composition of the organic template of different fractions of the frustule. In this study, we differentiate the whole cell basic washed fraction (FBW). The total frustule still contained the organic coating: the cleaned frustule is made up of $2 \mathrm{bSiO}_{2}$ phases but no organic coating; while the composition of the $\mathrm{bSiO}_{2}$ resulting from the basic treatment reflects the composition of the less reactive phase (see Fig. 1 for the chemical and physical treatments used to obtain
BGD

$7,5953-5995,2010$

\section{Impact of nutrient availability on frustule composition}

C. Soler et al.

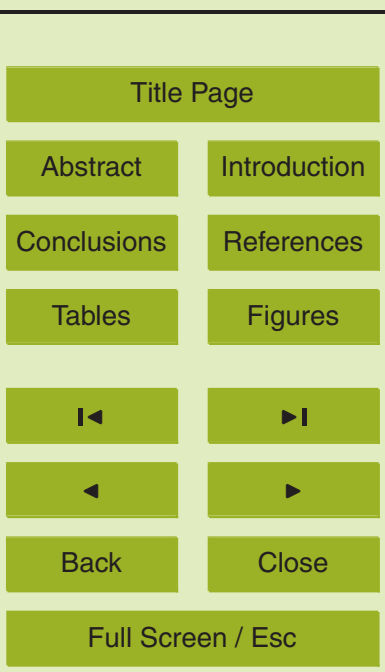

Printer-friendly Version

Interactive Discussion 


\subsection{Effects of nutrient starvation on the biochemical composition of frustule fractions}

BGD

\subsubsection{Comparison of FTIR spectra}

Comparisons of frustule fraction FTIR spectra are presented on Fig. 5 for the 4 growth 5 conditions.

Total frustule fraction (TF) - diatom total frustule fraction, which is composed of the frustule plus its organic coating, was isolated from diatoms grown under all nutrient starvation conditions. FTIR spectra of all total frustules are compared on Fig. 5a. The degree of similarity between the different frustule fractions was tested with a cluster 10 analysis (Fig. 6). Cluster analysis gave satisfying results, as all duplicates were coupled together. General spectra showed that starvations strongly affected the biochemical composition of the total frustule. $\mathrm{Si}(\mathrm{OH})_{4}$ starvation had less impact on the total frustule composition than $\mathrm{NO}_{3}$ starvation and $\mathrm{PO}_{4}$ starvation.

Physical and chemical treatments of cell pellets to isolate the frustule fraction removed the internal organic matter pool. In the protein pool of the total frustule fraction, the band attributed to amide I was reduced compared to amide II, which was more visible (Fig. 5a: bands 2 and 3) except for $\mathrm{PO}_{4}$ starvation spectra where amide II and amines were not dissociable even after deconvolution. The protein pool of $\mathrm{PO}_{4}$ starved frustule was particularly dominated by amide II and amine functions whereas the amide I function presented the highest peak in the protein pool of the 3 other spectra (Fig. 5a). Carbohydrates were the second major component of the total frustule. However, the group of bands attributed to carbohydrates, between 1300 and $1100 \mathrm{~cm}^{-1}$ (Fig. 5a: band 5), was different from the band observed for the whole-cell spectra (Fig. 3: band 5). Indeed, in the total frustule spectra, this band was thinner
7, 5953-5995, 2010

Impact of nutrient availability on frustule composition

C. Soler et al.

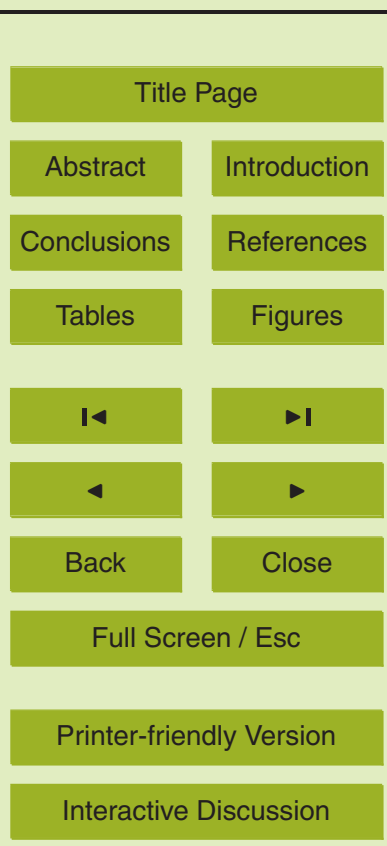


Biogenic silica was also a dominant compound of the total frustule fraction. Band 6 was the highest peak in the FTIR spectra (Fig. 5: band 6). This band was reduced in the $\mathrm{PO}_{4}$-starved total frustule spectra compared to the 3 other growth conditions. With regard to the lipid fraction, the band corresponding to the $\mathrm{C}=\mathrm{O}$ stretch of the ester 5 function $\left(1740 \mathrm{~cm}^{-1}\right)$ was not visible on the frustule spectra except on the total frustule extracted from $\mathrm{PO}_{4}$-starved cells. However, vibrations assigned to the $\mathrm{C}-\mathrm{H}$ stretch of saturated $\mathrm{CH}$ of lipids were observed between 2800 and $3000 \mathrm{~cm}^{-1}$ (not shown on Fig. 5).

Frustule acid washed fraction (FAW) - acid treatments are used in electronic microscopy to clean frustules from its external organic coating to ameliorate microscopic observations (Round, 1990). In this study, we used this treatment to eliminate most of the organic matter present on the frustule to evaluate the composition of the organic coating and frustule phases. The FTIR spectra of the FAW fraction were compared to those of diatomite (Fig. 5b). Diatomite FTIR spectra indicate the purity of the biogenic the silica band appeared (Fig. 5b). A comparison between the FAW fraction and the diatomite spectra confirmed that some organic matter remained after the organic coating was removed by acid cleaning. For the 4 growth conditions, the vibration bands between 1300 and $1000 \mathrm{~cm}^{-1}$ (Fig. $5 \mathrm{~b}$ : bands 5 and 6) were close to each other, 20

whereas differences were observed among growth conditions in whole cells and in the frustule fraction (Figs. 3 and $5 \mathrm{a}$ ). Band 5 assigned to carbohydrates was already reduced for $\mathrm{Si}(\mathrm{OH})_{4}$ and $\mathrm{PO}_{4}$ starvations in the frustule fraction (Fig. 5). A part of the carbohydrate pool in the control and $\mathrm{NO}_{3}$-starved cells was only released after nitric acid treatment. The second band in this spectral region corresponds to the 3 peaks asband 6). In the FAW fraction, protein pools were easier to differentiate compared to the total frustule fraction, and the acid treatment seemed to have released more amide II than amide I or amine (Fig. 5a,b). The organic matter pool remained important in the FAW fraction, and the strength of these Si-OC interactions were tested by dissolving

BGD

7, 5953-5995, 2010

\section{Impact of nutrient availability on frustule composition}

C. Soler et al.

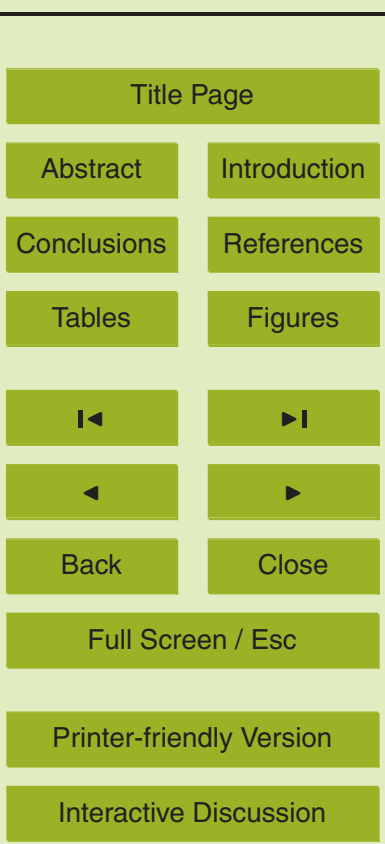

Interactive Discussion 
$\mathrm{bSiO}_{2}$ with a basic attack.

Frustule basic washed fraction (FBW) - as previously described, basic treatments were applied to dissolve most of the $\mathrm{bSiO}_{2}$ (more than $85 \%$ ) and its associated organic matter. The composition of the remaining fraction reflects the composition of the less

5 reactive phase forming the frustule. The FTIR spectra (Fig. 5c) clearly showed the main protein contributions, with the high and large bands observed between 1300 and $1750 \mathrm{~cm}^{-1}$. The amide II was the most expressed protein function (Fig. 5c: band 3). Comparison of the fourth spectra indicated an impact of nutrient starvation. The carbohydrate and the $\mathrm{bSiO}_{2}$ bands (Fig. 5: band 5 and 6, respectively) were reduced 10 for the $\mathrm{PO}_{4}$ - and $\mathrm{Si}(\mathrm{OH})_{4}$-starved frustules.

Comparison of the FTIR spectra of the different frustule fractions showed more differences among nutrient starvations in the total frustule fraction than in the frustule acid washed or the basic acid washed fractions. Note that organic matter was still highly involved in the frustule structure, which highlighted the strength of these Si-OC inter15 actions in the different frustule fractions. The relative contribution of each biochemical pool was estimated by the integration of peak areas observed on deconvolved FTIR spectra.

\subsubsection{Relative biochemical composition of frustule fractions}

Total frustule (TF) - organic matter still dominated the total frustule fraction, with a con20 tribution to the global composition estimated at $\sim 74 \%$ and $\sim 79 \%$ for the $\mathrm{PO}_{4}$-starved frustules (Fig. 7). Proteins clearly dominated the organic matter pool, reaching $34 \%$, $36 \%$, and $37 \%$ of the global composition of $\mathrm{NO}_{3}$-starved, $\mathrm{SiOH}_{4}$-starved, and control frustules, respectively, and $48 \%$ for the $\mathrm{PO}_{4}$-starved frustules (Fig. 7). Amide II and amine fractions contributed to $36 \%$ of the global composition of $\mathrm{PO}_{4}$-starved total frustules and dominated the protein pool (Fig. 7). In the 3 other growth conditions, the amide I fraction was the major contributor to the protein pool (Fig. 7: 14\% for control, $13 \%$ for $\mathrm{NO}_{3}$ starvation, and $14 \%$ for $\mathrm{Si}(\mathrm{OH})_{4}$ starvation). Amide I to amide II ratio was reduced from whole cells to total frustule fraction. This ratio decreased by a factor of

\section{BGD}

7, 5953-5995, 2010

\section{Impact of nutrient availability on frustule composition}

C. Soler et al.

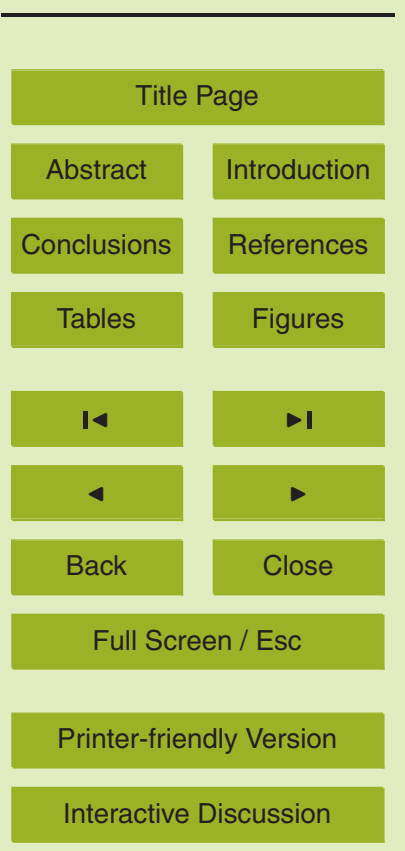


4 for $\mathrm{PO}_{4}$-starved total frustules (from 1.5 to 0.35 ), by 3 for $\mathrm{Si}(\mathrm{OH})_{4}$-starved total frustules (from 3.5 to 1.3), and by more than 2 for control and NO3-starved total frustules (from 3 to 1.3).

The relative contribution of carbohydrate was $28 \%$ for control and $\mathrm{Si}(\mathrm{OH})_{4}$-starved 5 total frustules, $27 \%$ for $\mathrm{NO}_{3}$-starved total frustules, and only around $20 \%$ for $\mathrm{PO}_{4}$ starved total frustules (Fig. 7).

Biogenic silica was the third major component of the total frustule fraction, except for $\mathrm{PO}_{4}$-starved total frustule where carbohydrate was slightly lower. The contribution of total silica was estimated to be around $26 \%$ of the global composition for control, $10 \mathrm{NO}_{3}$-starved, and $\mathrm{Si}(\mathrm{OH})_{4}$-starved total frustules, and only $21 \%$ for the $\mathrm{PO}_{4}$-starved total frustules (Fig. 7).

Total lipid contribution to the total frustule fraction composition was similar to the whole-cell diatom and contributed to around $10 \%$ of the global composition of the total frustule fraction (Fig. 7).

15 Frustule acid washed (FAW) - in the frustule acid washed fraction, organic matter contribution was $64 \%, 66 \%, 65 \%$, and $60 \%$ for control, $\mathrm{NO}_{3}$-starved $\mathrm{FAW}, \mathrm{Si}(\mathrm{OH})_{4}$ starved FAW, and $\mathrm{PO}_{4}$-starved FAW, respectively (Fig. 7).

Protein contributions decreased, and their global contribution to the composition of FAW fractions isolated from $\mathrm{PO}_{4}$-starved cells, $\mathrm{Si}(\mathrm{OH})_{4}$-starved cells, control cells, and $\mathrm{NO}_{3}$-starved cells became $27 \%, 33 \%, 34 \%$, and $36 \%$, respectively (Fig. 7). Acid treatment released more amides, whereas amine contributions were almost unchanged in the 3 diatom fractions (Fig. 7: WC, TF, FAW) for control, $\mathrm{NO}_{3}$-starved, and $\mathrm{Si}(\mathrm{OH})_{4}{ }^{-}$ starved cells. $\mathrm{PO}_{4}$ starvation reduced the protein pool in the frustule, which was reduced compared to the other growth conditions. The amine fraction composed the highest fraction of the protein pool in whole cells and total frustules, whereas the amide I fraction was dominant in cleaned frustules (Fig. 7).

The relative contribution of carbohydrates was higher in $\mathrm{Si}(\mathrm{OH})_{4}$ and $\mathrm{PO}_{4}$ starvations, $25 \%$ and $28 \%$, respectively, compared to $22 \%$ for control and $\mathrm{NO}_{3}$-starved cells (Fig. 7).
BGD

7, 5953-5995, 2010

\section{Impact of nutrient availability on frustule composition}

C. Soler et al.

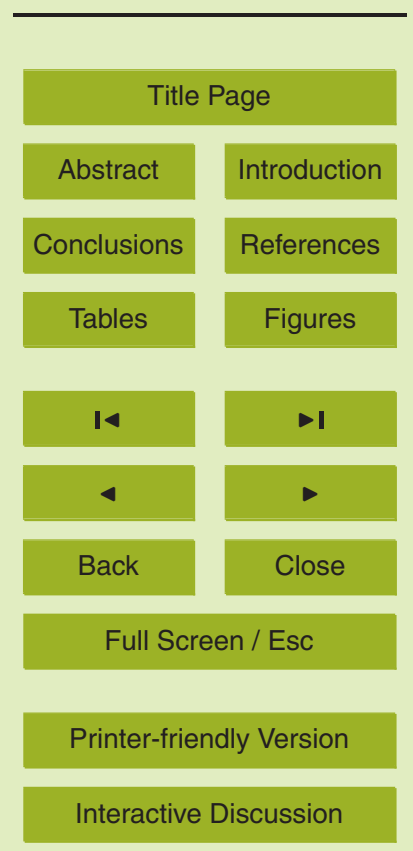


The total $\mathrm{bSiO}_{2}$ pool reached $36 \%$ of the global composition for the control FAW fraction, $35 \%$ for the $\mathrm{Si}(\mathrm{OH})_{4}$-starved $\mathrm{FAW}$ fraction, 34\% for the $\mathrm{NO}_{3}$-starved FAW fraction, and $40 \%$ for the $\mathrm{PO}_{4}$-starved FAW fraction (Fig. 7 ).

The composition of frustule acid washed fractions showed fewer differences than 5 those observed in whole cells or total frustule fraction. The organic matter released by nitric acid treatment should vary depending on growth conditions. The difference between the relative biochemical compositions of the total frustule fraction and the FAW fraction gave the relative contribution of each biochemical pool to the more reactive organic matter phases, which we assumed to be the organic coating.

10 Organic coating $(\mathrm{OC})$ - the relative biochemical composition of the organic coating is compared for the 4 growth conditions on Fig. 6 . The impact of nutrient starvation on the composition of the organic coating was significant, as shown by the variations in carbohydrate, protein, and lipid contributions.

Proteins are the most dominant components of the organic coating fractions of 15 the control, $\mathrm{Si}(\mathrm{OH})_{4}$-starved, and $\mathrm{PO}_{4}$-starved cell (Fig. 7). $\mathrm{PO}_{4}$-starved cells again showed more differences, with a protein contribution reaching $71 \%$ of this fraction versus $45 \%, 44 \%$, and $28 \%$ for organic coating extracted from the control total frustule (TF) fraction, $\mathrm{Si}(\mathrm{OH})_{4}$-starved TF fraction, and $\mathrm{NO}_{3}$-starved TF fractions (Fig. 7).

Carbohydrates were considerably reduced in the coating of $\mathrm{PO}_{4}$-starved cells com20 pared to the coating of control (Fig. 7: 11\%), $\mathrm{NO}_{3}$-starved, and $\mathrm{SiOH}_{4}$-starved (Fig. 7: $43 \%, 43 \%$, and $37 \%$, respectively) cells.

Lipid contribution slightly increased for the coating of $\mathrm{PO}_{4}$ and $\mathrm{Si}(\mathrm{OH})_{4}$-starved cells compared to the coating of control cells (Fig. 7: $18 \%$ and $19 \%$ versus $12 \%$ ). The effect of $\mathrm{NO}_{3}$ starvation was less severe, resulting to an important accumulation of lipids 25 (Fig. 7: $29 \%$ versus 12\% for the organic coating of control cells).

Frustule basic washed (FBW) - the protein contribution to this less reactive frustule phase was significant (Fig. 7: $79 \%$ for the control; $71 \%$ for $\mathrm{NO}_{3}$ starvation; $81 \%$ for $\mathrm{Si}(\mathrm{OH})_{4}$ and $\mathrm{PO}_{4}$ starvations, respectively).
BGD

$7,5953-5995,2010$

\section{Impact of nutrient availability on frustule composition}

C. Soler et al.

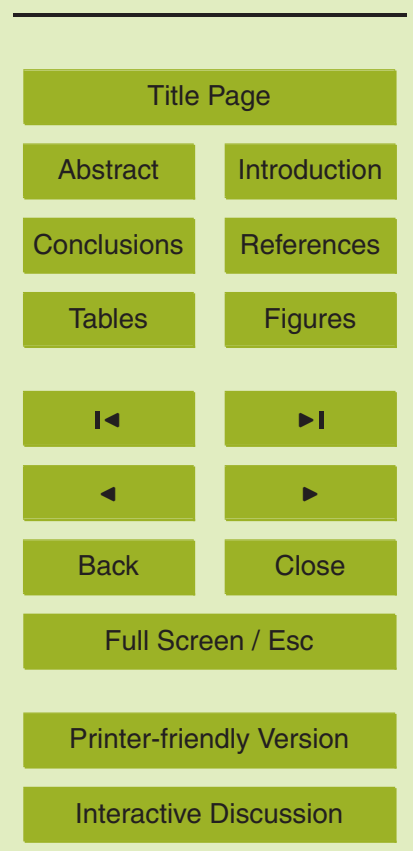


Amide II was the most expressed protein fraction, with a contribution reaching $34 \%$, $25 \%, 37 \%$, and $30 \%$ of the $\mathrm{FBW}$ fraction for control, $\mathrm{NO}_{3}$ starvation, $\mathrm{Si}(\mathrm{OH})_{4}$ starvation, and $\mathrm{PO}_{4}$ starvation, respectively (Fig. 7). Amine contribution was relatively constant for the 4 growth conditions: around $27 \%$, although $\mathrm{PO}_{4}$ starvation showed a slightly higher 5 value (Fig. 7: 31\%). Note that $\mathrm{NO}_{3}$ starvation reduced the amount of amide II in the frustule basic washed fraction, leading to a decrease in the total protein contribution (Fig. 7: $71 \%$ versus $79 \%$ for the control).

In all conditions, lipids and carbohydrates were less involved in the composition of the FBW fraction, with a contribution of less than $10 \%$ of the global biochemical com10 position. The contribution of $\mathrm{bSiO}_{2}$ in this phase was reduced for $\mathrm{Si}(\mathrm{OH})_{4}$ and $\mathrm{PO}_{4}$ starvations (Fig. 7: $9 \%$ and $7 \%$, respectively) in comparison with control and $\mathrm{NO}_{3}$ starvation (Fig. 7: 15\% and 16\%, respectively).

\subsubsection{Comparison of $\mathrm{Si}-\mathrm{OC}$ interactions}

Although the quality of the organic mater efficiently trapped and protected by the $\mathrm{bSiO}_{2}$ matrix was not obviously affected by nutrient starvation, the contribution of each biochemical pool varied. To compare the Si-OC interaction in the frustule phases, different ratios were calculated between $\mathrm{bSiO}_{2}$ and the 3 main organic matter pools (carbohydrate, protein, and lipid) for the different frustule phases (total, cleaned, and less reactive phases) extracted from cells grown under various nutrient starvation conditions 20 (Fig. 8).

The $\mathrm{bSiO}_{2}$-to-lipid ratio was clearly the most variable depending on the fraction and the growth condition; however, in all cases, it gave the highest ratio. On the contrary, the $\mathrm{bSiO}_{2}$-to-carbohydrate ratio was identical for the 4 growth conditions: 1 for the total frustules and 1.8 for the cleaned frustules (Fig. 8). This ratio only varied in the less

reactive frustule phase, with a decrease of the ratio from the control to $\mathrm{PO}_{4}$ starvation (Fig. 8: from 4.5 to 1, respectively). Finally, the $\mathrm{bSiO}_{2}$-to-protein ratio was the most stable among the 3 ratios calculated. Although slight variations between fractions were observed, this ratio was equal for the 4 growth conditions within each fraction (Fig. 8: $0.8,1$, and 0.25 for the total, cleaned, and less reactive frustule fractions, respectively).
BGD

7, 5953-5995, 2010

\section{Impact of nutrient availability on \\ frustule composition}

C. Soler et al.

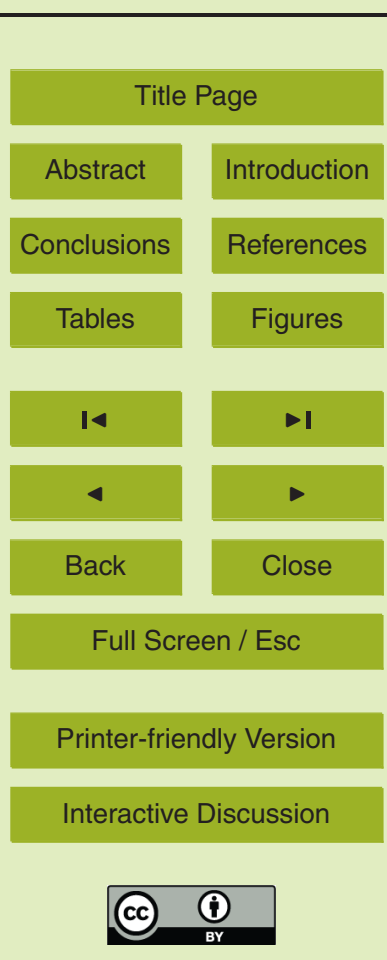




\section{Discussion}

\subsection{Impact of nutrient starvations on photosynthetic parameters}

The variations in photosynthetic parameters induced by nutrient stresses indicated changes in diatom physiology. A decrease in $F_{\mathrm{v}} / F_{\mathrm{m}}$ in $T$. weissflogii, similar to our 5 findings (Table 1), was reported for nitrogen (Berges et al., 1996; Lippemeier et al., 2001) and silicon and phosphorus (Lippemeier et al., 2001) starvations. Lippemeier and coworkers also showed that the recovery of fluorescence parameters after the readdition of the deficient nutrient was faster for $\mathrm{Si}(\mathrm{OH})_{4}$ - and $\mathrm{PO}_{4}$-starved cells than for $\mathrm{NO}_{3}$-starved cells. However, their starvation period lasted for only 3 days, whereas in this study, cells were starved for more than a week. Consequently, changes on the photosynthetic apparatus were more pronounced. The variations in photosynthetic capacity (ETRmax) and efficiency $(\alpha)$ were observed for all batch cultures (Fig. 2). Decrease of the photosynthetic capacity was delayed for $\mathrm{NO}_{3}$ starvation. ETR was in the same range as the control after 4 days (T4) of starvation, whereas after 7 days the ETRmax of $\mathrm{NO}_{3}$-starved cells decreased to $0.38 \mu_{\mathrm{mol} \mathrm{e}}^{-1}\left(\mathrm{mg} \mathrm{Chl}^{-a}\right)^{-1} \mathrm{~s}^{-1}$ (Table 1). The major effect of nitrogen starvation occurred in photosystem II (Berges et al., 1996) which make diatoms the most sensitive phytoplankton group because of their higher abundance of photosystem II centers versus PSI centers (74\% of photosystem II) (Johnsen and Sakshaug, 2007). This modification of the physiologic state of cells could corduring photosynthesis, and carbohydrates are accumulated as energy reserves and are used in protein synthesis and growth (Barlow, 1982; Mague et al., 1980). The FTIR spectra gave the relative contribution of each pool to the global composition of diatom cells. Nitrogen starvation seemed to have few effects on the distribution of the different

biochemical pools of $T$. weissflogii, as the relative composition of $\mathrm{NO}_{3}$-starved cells

was similar to the composition of the control (Fig. 7). These results were surprising because nitrate stress is expected to induce a decrease of the protein pool (Guerrini et al., 2000). However, biochemical analyses of the global total protein pool in whole

BGD

$7,5953-5995,2010$

Impact of nutrient availability on frustule composition

C. Soler et al.

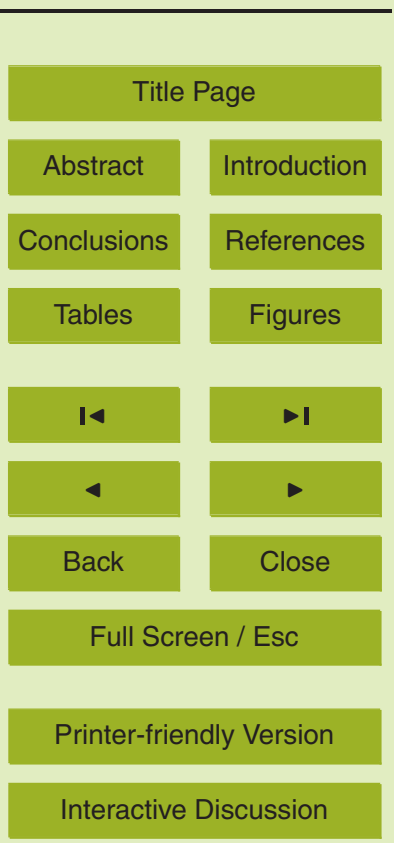


cells were performed for the different growth conditions (unpublished data), and no significant decrease was observed for $\mathrm{NO}_{3}$ starvation. An increase of lipid and carbohydrate pools was reported in previous studies (Shifrin and Chisholm, 1981; Guerrini et al., 2000); however, we observed different results. Cells growing under stress condi5 tions modified the distribution of biochemical pools to maintain their metabolism (Giordano et al., 2001; Giordano and Bowes, 1997; Falkowski, 1994). Nutrient stresses applied in the present study were severe in terms of intensity (starvation) and their sudden application. Contrary to limitations, starvations stop the cell division and the organic matter pools are conserved and not allocated to daughter cell metabolism. The 10 delay observed on the reduction of photosynthesis of $\mathrm{NO}_{3}$-starved cells could be explained by an important reserve pool of nitrate. During the first day of the experiment, $\mathrm{NO}_{3}$-starved cells used their reserves to maintain basal metabolism. After 4 days, the photosynthetic activity of $\mathrm{NO}_{3}$-starved cells was reduced from $1.0 \mu \mathrm{mol} \mathrm{e}^{-1}$ (mg Chl$\left.\mathrm{a}^{-1}\right) \mathrm{s}^{-1}$ to $0.6 \mu \mathrm{mol} \mathrm{e}^{-1}\left(\mathrm{mg} \mathrm{Chl}-\mathrm{a}^{-1}\right) \mathrm{s}^{-1}$; to $0.4 \mu \mathrm{mol} \mathrm{e}^{-1}\left(\mathrm{mg} \mathrm{Chl}-\mathrm{a}^{-1}\right) \mathrm{s}^{-1}$ after 7 days

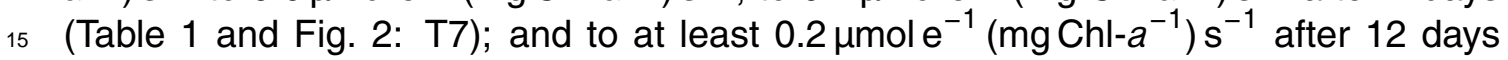
(Table 1 and Fig. 2: T12).

$\mathrm{PO}_{4}$ starvation had drastic effects on diatom physiology. Cells were not able to maintain the photosynthetic activity, and ETRmax decreased to below $0.2 \mu \mathrm{mol}^{-1}$ (mg Chl$\left.a^{-1}\right) \mathrm{s}^{-1}$ and stopped after 7 days (Table 1 and Fig. 2). Phosphorus is a key element 20 for cell division, is involved in DNA replication and in many chemical reactions that are ATP dependent, and is essential for phospholipid synthesis. Deprivation of $\mathrm{PO}_{4}$ directly affected the activity of the phosphatase but also increased the activity of several enzymes that are not P-dependent (Theodorou et al., 1991). The FTIR spectra of $\mathrm{PO}_{4}$ starved cells clearly indicated an accumulation of carbohydrate and protein in diatom cells. Although carbohydrates were dominant in total cells, more than any other condition, the relative contribution of each pool remain unchanged compared to the control. In fact, the FTIR spectra showed that lipid, carbohydrate, silica, and protein pools all increased compared to the other conditions (Fig. 3). Only the amines increased in proportion among the proteins (Fig. 4d). Guerrini et al. (2000) proposed that the increase
BGD

$7,5953-5995,2010$

\section{Impact of nutrient availability on frustule composition}

C. Soler et al.

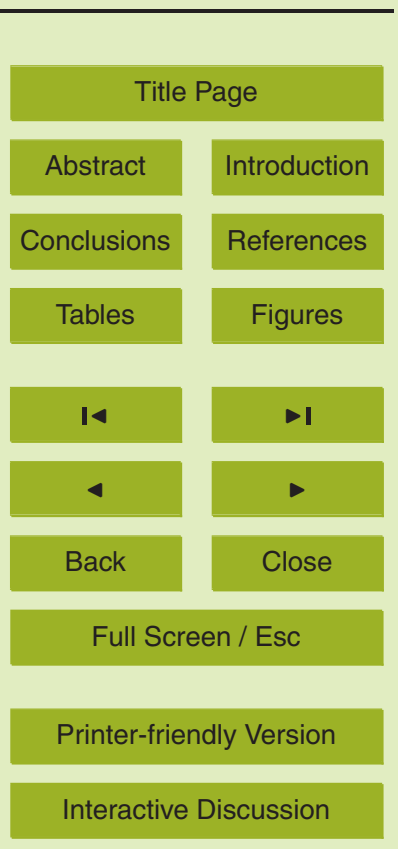


in carbohydrate production was due to a general decrease of catabolism coupled with a decline of the utilization of storage compounds. $\mathrm{PO}_{4}$ starvation slowed down photosynthesis and general metabolism, and at least stopped cell division. In fact, $\mathrm{PO}_{4}$ depletion led to an accumulation of photosynthetic products, although a part of this 5 surplus is probably excreted in the external medium.

$\mathrm{Si}(\mathrm{OH})_{4}$ starvation also had a strong and immediate effect on the photosynthetic capacity. ETRmax was reduced to $0.2 \mu \mathrm{mol}^{-1}\left(\mathrm{mg} \mathrm{Chl}^{-1} \mathrm{a}^{-1}\right)$ and, contrary to $\mathrm{NO}_{3}$ and $\mathrm{PO}_{4}$ starvation, ETR remained more or less constant throughout the experiment (Table 1 and Fig. 2). Silicic acid uptake could proceed both in the dark and in the 10 light, confirming that this step of silicification is not directly coupled with photosynthesis (Claquin and Martin-Jezequel, 2005). Recent studies showed that the polycondensation of biogenic silica required proteins (Kröger et al., 1999, 2000; Poulsen and Kröger, 2004; Poulsen et al., 2003). Indeed, to build up the frustule, silicic acid is concentrated in an intracellular organelle called silica-deposition vesicle (SDV), where silicic acid is 15 polymerized to form $\mathrm{bSiO}_{2}$. Studies carried out by Kröger and collaborators isolated peptides known as silaffins, which participate in biomineralization processes within the SDV. FTIR structural analysis revealed a reduction of the relative biogenic silica (Figs. 3 and 4c: $10 \%$ ). Organic matter was clearly dominated by proteins (more than $50 \%$ ), and the relative contribution of the carbohydrate pool decreased (Fig. 4c). A higher contribution of proteins in silica-starved cells could be explained by the accumulation of the final product of photorespiration or by the accumulation of the catalytic products of silicification, which is stopped because of the lack of dSi. Serine and glycine, which are provided as the main fraction of the protein matrix of the frustule structure, are both final products of diatom photorespiration (Lippemeier et al., 1999) and catalyzers of silicification (Kröger and Poulsen, 2008 and references therein). As cell division was reduced by the depletion of silicic acid, these amino acids will accumulate in the cells. However, Claquin and coworkers (2004) highlighted that photorespiration was significantly reduced in diatom cells. As the cell division was reduced by the depletion of silicic acid these amino acids will accumulate in the cells. The proportion of
BGD

$7,5953-5995,2010$

\section{Impact of nutrient availability on frustule composition}

C. Soler et al.

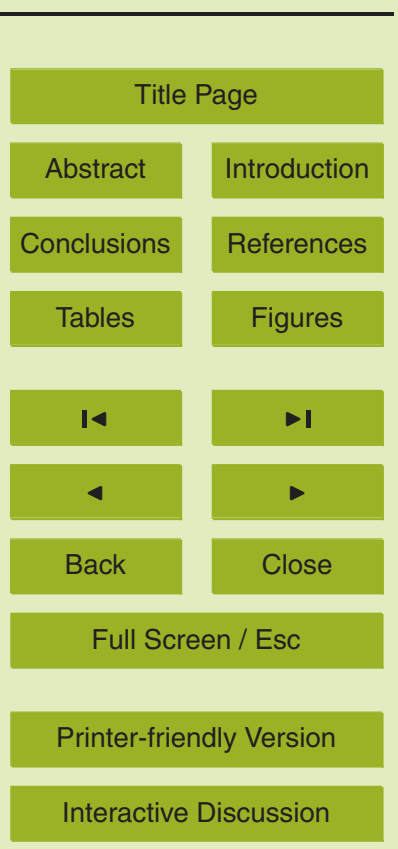

Interactive Discussion 
energy allocated to photorespiration processes could be potentially accentuated under nonoptimal growth conditions. The FTIR study indicates a reduction of carbohydrate contribution to Si-starved cells (Fig. 4c), which is most probably due to a higher excretion of carbohydrates in the medium. It is well known that under nutrient stress, the 5 excess photosynthetic products are excreted as EPS or TEP (Underwood et al., 2004; Staats et al., 2000; Passow, 2002).

As expected, nutrient starvation affected the relative contribution of the main biochemical pool to diatom cell composition. Diatoms play an important role in the biogeochemical cycle of carbon and especially in carbon export. The key role of diatoms 10 in carbon export is due to their ability to enter large particles, such as aggregates or fecal pellets, and also due to their frustules, which can function as ballasts in single cells and in larger particles (Buesseler, 1998; Ragueneau et al., 2006). Consequently, understanding the effects of nutrient starvation on diatom frustule biochemical composition is important.

$15 \quad 4.2$ Impact of nutrient starvation on total and cleaned frustule compositions

To our knowledge, no other studies have determined the effect of different growth conditions on frustule composition. In the total frustule fraction, the organic matter pool was still important compared to the biogenic silica, and the different nutrient starvation conditions did not have the same impact on the main biochemical pools.

$20 \mathrm{NO}_{3}$ starvation led to a small accumulation of lipids in the total frustule fraction (Fig. 7b), but did not affect the other pools. Moreover, the FTIR spectra of the $\mathrm{NO}_{3}$ starved frustule were close to the spectra of the control total frustule (Fig. 5a). The storage of lipids in cells has been previously associated with nutrient supply (Shifrin and Chisholm, 1981). In this study, however, lipid accumulation has been only shown

for $\mathrm{NO}_{3}$ and $\mathrm{PO}_{4}$ starvations. In total frustule of $\mathrm{PO}_{4}$-starved cells, more lipids were trapped in the frustule compared to control or $\mathrm{Si}(\mathrm{OH})_{4}$-starved frustules (Fig. 7). However, $\mathrm{PO}_{4}$ starvation was the only condition to induce an important shift of dominance among proteins from amide I to amide II and amines (Figs. 5a and 7). This shift could greatly impact the frustule architecture. The polycondensation of biogenic silica vary

BGD

$7,5953-5995,2010$

Impact of nutrient availability on frustule composition

C. Soler et al.

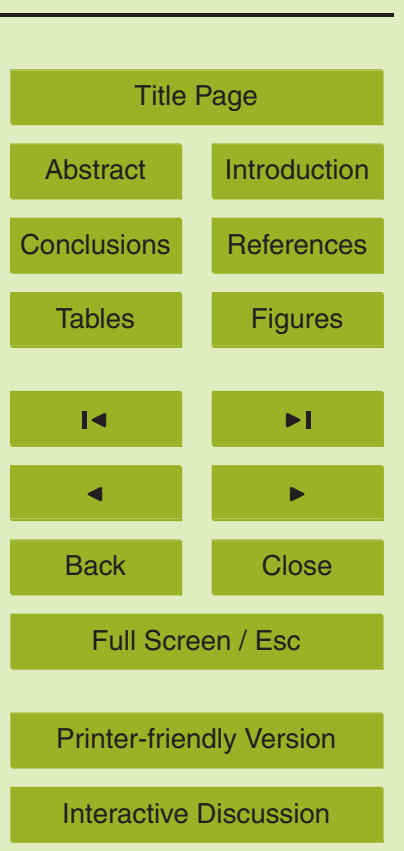

Interactive Discussion 
with the type of the protein present in the SDV (Kröger and Poulsen, 2008). Kröger et al. $(1999,2000,2001)$ identified different complex proteins involved in frustule formation that are characterized by secondary and tertiary amine bonds. The fact that the protein pool is changing with growth conditions could have an important impact on 5 frustule composition and architecture. The diatom frustule structure has a very complex architecture made up of nonuniform $\mathrm{bSiO}_{2}$, which could eventually be explained by 2 silicification models involved during frustule formation (Vartanian et al., 2009). The first model is a diffusion-limited aggregation model (DLA) (Gordon and Drum, 1994; Parkinson et al., 1999), which is assumed to form dendrite-like structures observed in 10 the diatoms. The second model was established to explain the areola structures of diatoms. This phase separation model was developed from observations of the Coscinodiscus species (Sumper, 2002). In the first model, the need for organic matter is less obvious than in the second one, in which the $\mathrm{bSiO}_{2}$ phase is produced around a complex organic matter layer that is potentially incorporated inside the $\mathrm{bSiO}_{2}$ matrix 15 or degraded after the synthesis of the mineral phase. Organic matter plays a crucial role in frustule formation. The significant changes observed in the protein pool of $\mathrm{PO}_{4}$ starved frustules (Fig. 7) could explain the decrease of biogenic silica contribution in those frustules. We also saw in whole cells that $\mathrm{PO}_{4}$ starvation led to a high production of carbohydrates, but the FTIR spectra of the frustule fraction indicated that most of them were not incorporated in the frustule matrix (Fig. 7). Carbohydrates were probably stored in the cells, and these reserves were not depleted due to fact that starvation stopped the cell division and consequently organic matter or $\mathrm{bSiO}_{2}$ pools were not allocated to daughter cells and could help to maintain cells basal metabolism. Then, a part of the reserve products can be released in the extracellular medium as shown by 25 Guerrini and coworkers (2000) for cells grown under $\mathrm{PO}_{4}$ depletion, releasing a high amount of polysaccharides in the extracellular medium.

Silica starvation also reduced the carbohydrate pool in the frustule (Fig. 5); however, proportionally, the composition of $\mathrm{Si}(\mathrm{OH})_{4}$-starved frustule did not differ significantly from control or $\mathrm{NO}_{3}$-starved frustules (Fig. 7). It was surprising that the contribution of
BGD

7, 5953-5995, 2010

\section{Impact of nutrient availability on frustule composition}

C. Soler et al.

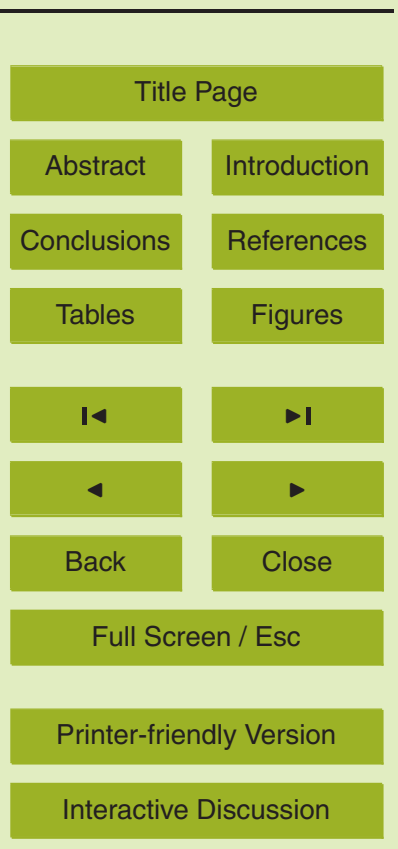


$\mathrm{bSiO}_{2}$ in the total frustule extracted from cells grown under $\mathrm{Si}(\mathrm{OH})_{4}$ was not reduced compared to the control. In batch culture, without renewal of the medium, a quick and efficient recycling of dead diatom cells is possible. However, nutrient concentrations were measured, and this revealed that the dissolved silica concentrations were low 5 throughout the experiment in the $\mathrm{Si}(\mathrm{OH})_{4}$-starved culture (unpublished data). The absence of $\mathrm{Si}(\mathrm{OH})_{4}$ starvation on the silicification of total frustule fraction could be due to a maintain of the basal metabolism allowed by the stop of cell division under starvation. It could also be due to the ability of diatoms to maintain a free pool of dissolved silica (Martin-Jézéquel et al., 2000 and reference therein) and eventually to the reallo10 cation of $\mathrm{bSiO}_{2}$ from the frustule to the free pool (Hildebrand and Wetherbee, 2003). A large part of the organic compounds present in the diatom cells had been released during frustule extraction. The ratio between amide I and amide II was much higher in whole cells than in total frustules. To improve our knowledge on frustule formation, the different frustule phases need to be characterized. The next step in exploring Si-OC

15 interactions inside the frustule was to isolate the organic matter strongly linked in the silicon template by removing the organic coating.

FTIR study indicated that nutrient impact on cleaned frustules was reduced compared to those observed on total frustule (Fig. 5a) or on whole cells (Fig. 3). The 4 FTIR spectra were closely similar, and the silica peak fit well with the diatomite standard (Fig. 5b). Notably, cleaned frustule fractions present a large amount of organic matter: $65 \%$ of the global composition (Fig. 7). In fact, only $\mathrm{PO}_{4}$ starvation led to a reduction of protein fixation in the frustule matrix, compensated by a higher contribution of $\mathrm{bSiO}_{2}$ and carbohydrates. The role of lipids and carbohydrates in frustule formation is still unknown. Lipid contribution to the composition of frustule acid washed 25 fractions was not significantly affected by starvation; on the other hand, carbohydrate contributions were affected. Carbohydrates excretions, as EPS or TEP, are known to be emphasized under stress conditions (Underwood et al., 2004; Staats et al., 2000; Passow, 2002). The excretion of carbon will accelerate the formation of larger particles and aggregates, and that will affect the diatom remineralization rate.
BGD

$7,5953-5995,2010$

\section{Impact of nutrient availability on frustule composition}

C. Soler et al.

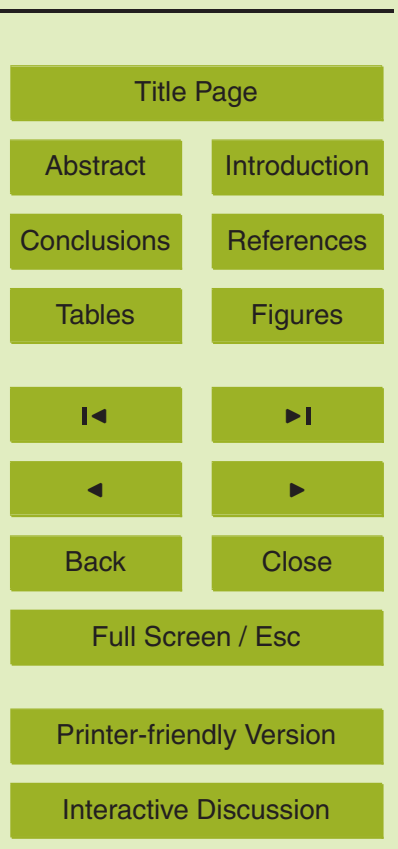




\subsection{Effects of biochemical composition changes in frustule phases on carbon export}

Degradation and dissolution of diatom will occur throughout cell sedimentation in the water column. The intensity of diatom remineralization at each depth results to the change in balance between remineralization and sedimentation rates. Sedimentation rates increase when diatoms are incorporated in larger particles such as fecal pellets or aggregates (Thornton, 2002). Nutrient starvation seem to generate a higher excretion of EPS especially for $\mathrm{PO}_{4}$ starvation (Guerrini et al., 2000), which can be quickly followed by aggregation. Nonoptimal growth conditions can potentially increase the quantity of exportable carbon. Diatom frustule is surrounded by an organic coating (Zurzolo and Bowler, 2001; Hecky et al., 1973; Swift and Wheeler, 1992), which is mainly composed of carbohydrates except under $\mathrm{PO}_{4}$ starvation, in which proteins are the most dominant component (Fig. 7). The modification of the biochemical composition of the organic layer linked to the frustule could also have an impact on the physical and chemical properties of the frustule. The parallel can be made with the abalone shell of which the increase of mechanical resistivity has been attributed to the organic matrix intimately link to the calcium carbonate (Hildebrand and Wetherbee, 2003). Consequently, a change in the organic coating composition will probably increase or decrease the efficiency of zooplankton grazing. Indeed, Hamm et al. (2003) showed the high resistivity of diatom frustule to mechanical stress like zooplankton grazing. Modifications of the grazing efficiency due to frustules composition variations may affect (positively or negatively) the remineralization of both organic matter and $\mathrm{bSiO}_{2}$. Interestingly, carbohydrate contribution to $\mathrm{PO}_{4}$ starved cells was similar to the control but decreased in the total frustule fraction and at the same time the contribution of $\mathrm{bSiO}_{2}$ was reduced. Carbohydrates are probably stored in the intracellular pool and may induce a higher excretion of carbon in the extracellular medium. Excretion of organic components possibly increases when cells are less silicified or compensating the decrease in protection. Being less protected by its frustule, diatoms find another means of
BGD

$7,5953-5995,2010$

Impact of nutrient availability on frustule composition

C. Soler et al.

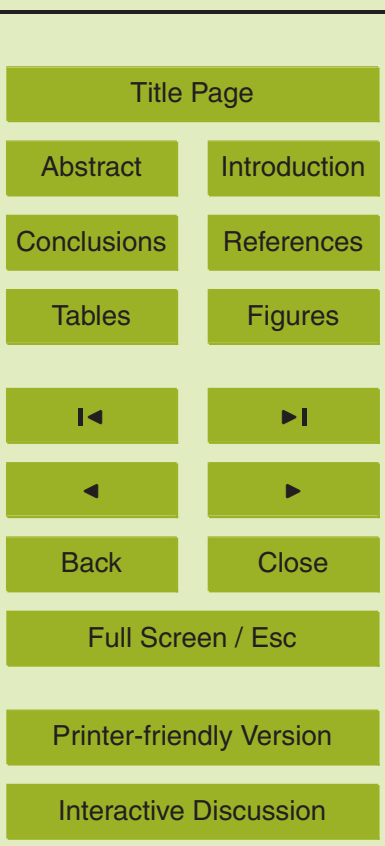


protection from small grazers and bacteria, by excreting a cloud of TEP around the cell and by forming large aggregates that contain higher nutrient concentrations (Moriceau et al., 2007).

Due to the coupling between $\mathrm{POC}$ degradation and $\mathrm{bSiO}_{2}$ dissolution, another im5 portant driver of the export of diatom carbon is $\mathrm{bSiO}_{2}$ dissolution. Recent studies done by Moriceau et al. (2009) indicated that $\mathrm{bSiO}_{2}$ has 2 phases, and that each phase has different dissolution properties. The authors hypothesized that this could be due to the strength of the Si-OC interactions. As organic layers are trapped in the diatom frustule (Hildebrand et al., 2006), the effect of starvations on this organic matter pool could 10 modify Si-C interactions and consequently modify the dissolution properties of the 2 phases. In the present study, the $\mathrm{bSiO}_{2}$ resulting from the basic attack was considered as a part of the less reactive frustule fraction. Proteins were the most important components of the frustule basic washed fraction. Proteins are key players of frustule silicification (Kröger et al., 1999, 2000, 2001; Poulsen and Kröger, 2004; Sumper and Kroger, 2004); their high contribution, especially amide II, suggests that after silicification, the proteins are incorporated in the frustule with the SDV and not released or excreted. The organic matter located in this fraction is assumed to be the most exportable one, as this pool is protected by the organic coating first and by another frustule phase, which is much more silicified. The less reactive frustule phase is composed of $85 \%$ to $90 \%$ of organic matter versus $10 \%$ to $15 \%$ of $\mathrm{bSiO}_{2}$ (Fig. 7 ). $\mathrm{Si}(\mathrm{OH})_{4}$ and $\mathrm{PO}_{4}$ starvations decrease the degree of silicification of this phase, whereas $\mathrm{NO}_{3}$ starvation was as silicified as the control. These nutrient starvations potentially increased the remineralization rate, although a large amount of organic matter can also slow down the remineralization processes.

\section{$25 \quad 5$ Conclusion and perspectives}

This study showed that the effects of nutrient starvation on the photosynthesis were severe even for the $\mathrm{Si}(\mathrm{OH})_{4}$ which is not considered to have a direct implication on
BGD

$7,5953-5995,2010$

\section{Impact of nutrient availability on frustule composition}

C. Soler et al.

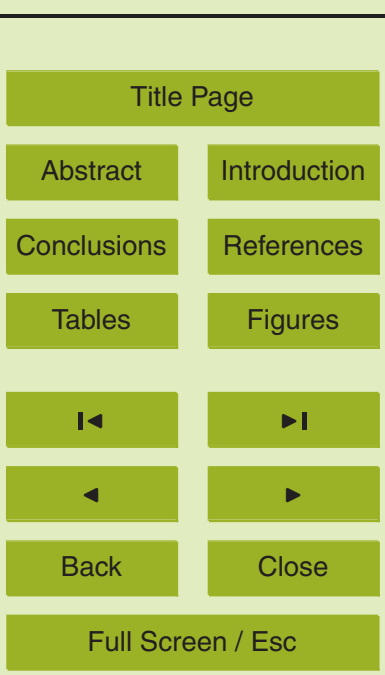

Printer-friendly Version

Interactive Discussion 
photosynthetic processes. Depending on the nutrient availabilities in surface water, the composition of the organic pool will be modified in diatoms. The composition changes were especially important for $\mathrm{PO}_{4}$ starvation. $\mathrm{Si}(\mathrm{OH})_{4}$ starvation reduced the global contribution of $\mathrm{bSiO}_{2}$ in whole cell and in the basic washed frustule frac5 tion. The silicification involved different type of proteins which are finally trapped in the frustule and consequently more exportable than other compounds. Carbohydrates are more reserved compounds that are excreted under non-optimal conditions in order to form larger particles and try to create a more favourable microhabitat. The organic pool associated with the frustule was impacted by nutrient starvations modifying the remineralization processes. The present study clearly highlights the drastic effects of $\mathrm{PO}_{4}$ starvation on the biochemical composition of all diatom fractions. Throughout the degradation and the dissolution of diatoms, organic compounds are rematerialized. As nutrient starvations impacted both whole diatom cells and frustule fractions, the quality and the quantity of the organic matter released in the water column will be highly vari-

able and partially controlled by diatom growth conditions. Simultaneous studies of silica dissolution and carbon degradation are required to obtain a greater understanding of the $\mathrm{Si}-\mathrm{OC}$ interactions and to clarify their role in diatom remineralization.

Acknowledgements. We would like to thank Amiel Caroline and Guibet Florence from the FTIR analytical centre of the University of Caen Basse-Normandie for providing support in performing

\section{References}

Antonides, L. E.: Diatomite: US Geological Survey Mineral Commodity Summaries, 56-57, 1998.

Barlow, R. G.: Phytoplankton ecology in the Southern Benguela Current. III. Dynamics of a bloom, J. Exp. Mar. Biol. Ecol., 63, 239-248, 1982.

Beardall, J., Berman, T., Heraud, P., Kadiri, M. O., Light, B. R., Patterson, G., Roberts, S., Sulzberger, B., Sahan, E., Uehlinger, U., and Wood, B.: A comparison of methods for detection of phosphate limitation in microalgae, Aquat. Sci., 63, 107-121, 2001.

BGD

$7,5953-5995,2010$

\section{Impact of nutrient availability on frustule composition}

C. Soler et al.

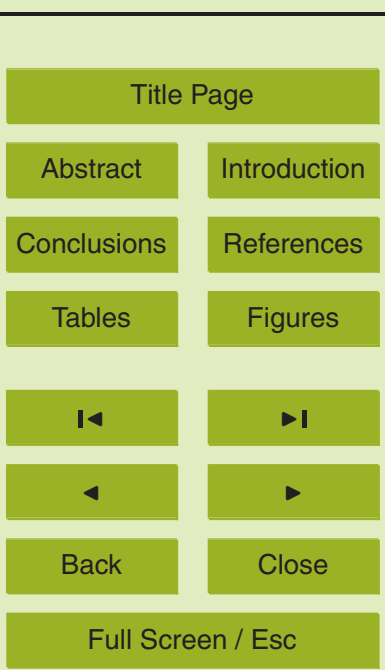

Printer-friendly Version

Interactive Discussion 
Benning, L. G., Phoenix, V. R., Yee, N., and Konhauser, K. O.: The dynamics of cyanobacterial silicification: an infrared micro-spectroscopic investigation, Geochim. Cosmochim. Ac., 68, 743-757, 2004.

Berges, J. A., Charlebois, D. O., Mauzerall, D. C., and Falkowski, P. G.: Differential effects of 5 nitrogen limitation on photosynthetic efficiency of photosystems I and II in microalgae, Plant Physiol., 110, 689-696, 1996.

Bidle, K. D. and Azam, F.: Accelerated dissolution of diatom silica by marine bacterial assemblages, Nature, 397, 508-512, 1999.

Brzezinski, M. A. and Nelson, D. M.: Chronic substrate limitation of silicic acid uptake rates in the Western Sargasso Sea, Deep-Sea Res. Pt. II, 43, 437-453, 1996.

Buesseler, K. O.: The decoupling of production and particulate export in the surface ocean, Global Biogeochem. Cy., 12, 297-310, 1998.

Claquin, P., Kromkamp, J. C., and Martin-Jezequel, V.: Relationship between photosynthetic metabolism and cell cycle in a synchronized culture of the marine alga Cylindrotheca fusiformis (bacillariophyceae), Eur. J. Phycol., 39, 33-41, 2004.

Claquin, P. and Martin-Jezequel, V.: Regulation of the Si and C uptake and of the soluble freesilicon pool in a synchronised culture of Cylindrotheca fusiformis (bacillariophyceae): effects on the Si/C ratio, Mar. Biol., 146, 877-886, 2005.

Coates, J.: Interpretation of infrared spectra, a practical approach, in: Encyclopedia of Analytical Chemistry, edited by: Meyers, R. A., John Wiley and Sons Ltd, Chichester, 10815-10837, 2000.

De La Rocha, C. and Passow, U.: Recovery of Thalassiosira weissflogii from nitrogen and silicon starvation, Limnol. Oceanogr., 49, 245-255, 2004.

Dubinsky, Z., Falkowski, P. G., and Wyman, K.: Light harvesting and utilization by phytoplankton, Plant Cell Physiol., 7, 1335-1349, 1986.

Dugdale, R. C., Wilkerson, F. P., and Minas, H. J.: The role of a silicate pump in driving new production, Deep-Sea Res. Pt. I, 42, 697-719, 1995.

Eilers, P. H. C. and Peeters, J. C. H.: A model for the relationship between light-intensity and the rate of photosynthesis in phytoplankton, Ecol. Model., 42, 199-215, 1988.

30 Falkowski, P. G.: The role of phytoplankton photosynthesis in global biogeochemical cycles, Photosynth. Res., 39, 235-258, 1994.

Fogg, G. E. and Thake, B.: Algal Culture and Phytoplankton Ecology, The University of Wisconsin Press, Wisconsin, 269 pp., 1987.
BGD

7, 5953-5995, 2010

\section{Impact of nutrient availability on frustule composition}

C. Soler et al.

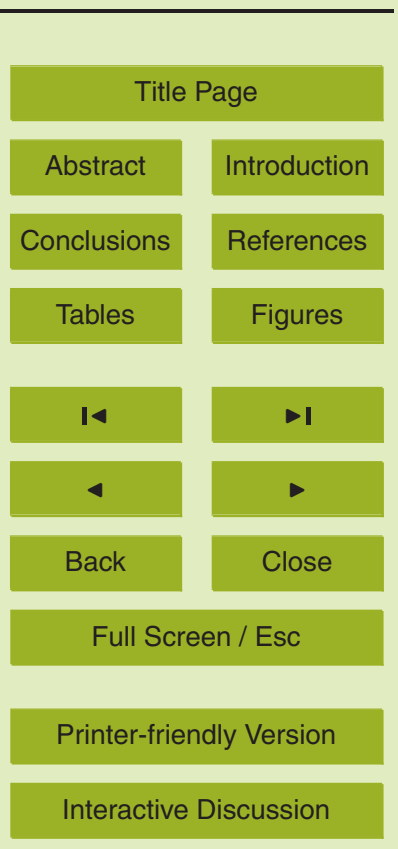


Gallinari, M., Ragueneau, O., Corrin, L., DeMaster, D. J., and Tréguer, P.: The importance of water column processes on the dissolution properties of biogenic silica in deep-sea sediments, I. Solubility, Geochim. Cosmochim. Ac., 66, 2701-2717, 2002.

Genty, B., Briantais, J. M., and Baker, N. R.: The relationship between the quantum yield of pho5 tosynthetic electron-transport and quenching of chlorophyll fluorescence, Biochim. Biophys. Acta, 990, 87-92, 1989.

Giordano, M. and Bowes, G.: Gas exchange and C allocation in Dunaliella salina cells in response to the $\mathrm{N}$ source and $\mathrm{CO}_{2}$ concentration used for growth, Plant Physiol., 115, 10491056, 1997.

10 Giordano, M., Kansiz, M., Heraud, P., Beardall, J., Wood, B., and McNaughton, D.: Fourier transform infrared spectroscopy as a novel tool to investigate changes in intracellular macromolecular pools in the marine microalga Chaetoceros muelleri (bacillariophyceae), J. Phycol., 37, 271-279, doi:10.1046/j.1529-8817.2001.00123.x, 2001.

Gordon, R. and Drum, R. W.: The chemical basis of diatom morphogenesis, Int. Rev. Cytol., 150, 243-372, 1994.

Granum, E. and Myklestad, S. M.: Effects of $\mathrm{NH}_{4}^{+}$assimilation on dark carbon fixation and b-1,3-glucan metabolism in the marine diatom Skeletonema costatum (bacillariophyceae), J. Phycol., 35, 1191-1199, 1999.

Granum, E. and Myklestad, S. M.: Mobilization of -1,3-glucan and biosynthesis of amino acids induced by $\mathrm{NH}_{4}^{+}$addition to $\mathrm{N}$-limited cells of the marine diatom Skeletonema costatum (bacillariophyceae), J. Phycol., 37, 772-782, 2001.

Guerrini, F., Cangini, M., Boni, L., Trost, P., and Pistocchi, R.: Metabolic responses of the diatom Achnanthes brevipes (bacillariophyceae) to nutrient limitation, J. Phycol., 36, 882890, 2000.

Guillard, R. R. L. and Ryther, J. H.: Studies of marine planktonic diatoms, I. Cyclotella nana hustedt and Detonela confervacea (cleve) gran, Can. J. Microbiol., 8, 229-239, 1962.

Guillard, R. R. L.: Purification methods for microalgae, in: Algal Culturing Techniques, edited by: Andersen, R. A., Elsevier Academic Press, Burlington, MA, USA, 117-132, 2005.

Hamm, C. E., Merkel, R., Springer, O., Jurkojc, P., Maier, C., Prechtel, K., and Smetacek, V.: Architecture and material properties of diatom shells provide effective mechanical protection, Nature, 421, 841-843, 2003.

Harrison, P. J., Waters, R. E., and Taylor, F. J. R.: A broad spectrum artificial seawater medium for coastal and open ocean phytoplankton, J. Phycol., 16, 28-35, 1980.
BGD

$7,5953-5995,2010$

\section{Impact of nutrient availability on frustule composition}

C. Soler et al.

Title Page

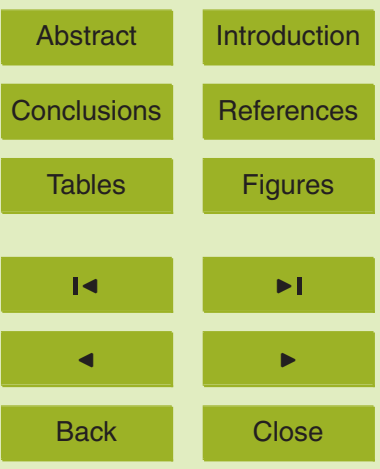

Full Screen / Esc

Printer-friendly Version

Interactive Discussion 
Hecky, R. E., Mopper, K., Kilham, P., and Degens, E. T.: The amino acid and sugar composition of diatom cell-walls, Mar. Biol., 19, 323-331, 1973.

Hildebrand, M. and Wetherbee, R.: Components and control of silicification in diatoms, in: Silicon Biomineralization: Biology, Biochemistry, Molecular Biology, Biotechnology. Progress

5 in Molecular and Subcellular Biology, 33, edited by: Mueller, W. E. G., Springer-Verlag, Heidelberg, Germany, 11-57, 2003.

Hildebrand, M., York, E., Kelz, J. I., Davis, A. K., Frigeri, L. G., Allison, D. P., and Doktycz, M. J.: Nanoscale control of silica morphology and three-dimensional structure during diatom cell wall formation, J. Mater. Res., 21, 2689-2698, 2006.

10 Hoagland, K. D., Rosowski, J. R., Gretz, M. R., and Roemer, S. C: Diatom extracellular polymeric substances: function, fine structure, chemistry and physiology, J. Phycol., 29, 537566, 1993.

Hofstraat, J. W., Peeters, J. C. H., Snel, J. F. H., and Geel, C.: Simple determination of photosynthetic efficiency and photoinhibition of Dunaliella-tertiolecta by saturating pulse fluorescence measurements, Mar. Ecol.-Prog. Ser., 103, 187-196, 1994.

Jansen, S.: Copepods grazing on Coscinodiscus wailesii: A question of size?, Helgoland Mar. Res., 62, 251-255, doi:10.1007/s10152-008-0113-z, 2008.

Johnsen, G. and Sakshaug, E.: Biooptical characteristics of PSII and PSI in 33 species (13 pigment groups) of marine phytoplankton, and the relevance for pulse-amplitude-modulated 20 and fast-repetition-rate fluorometry, J. Phycol., 43, 1236-1251, 2007.

Koski, M., Klein Breteler, W., and Schogt, N.: Effect of food quality on rate of growth and development of the pelagic copepod Pseudocalanus elongatus (copepoda, calanoida), Mar. Ecol.-Prog. Ser., 170, 169-187, 1998.

Koski, M., Breteler, W. K., Schogt, N., Gonzalez, S., and Jakobsen, H. H.: Life-stage-specific differences in exploitation of food mixtures: diet mixing enhances copepod egg production but not juvenile development, J. Plankton Res., 28, 919-936, 2006.

Kröger, N., Deutzmann, R., and Sumper, M.: Polycationic peptides from diatom biosilica that direct silica nanosphere formation, Science, 286, 1129-1132, 1999.

Kröger, N., Deutzmann, R., Bergsdorf, C., and Sumper, M.: Species-specific polyamines from diatoms control silica morphology, P. Natl. Acad. Sci. USA, 97, 14133-14138, 2000.

Kröger, N., Deutzmann, R., and Sumper, M.: Silica-precipitating peptides from diatoms - the chemical structure of silaffin-1a from Cylindrotheca fusiformis, J. Biol. Chem., 276, 2606626070, 2001.

BGD

7, 5953-5995, 2010

\section{Impact of nutrient availability on frustule composition}

C. Soler et al.

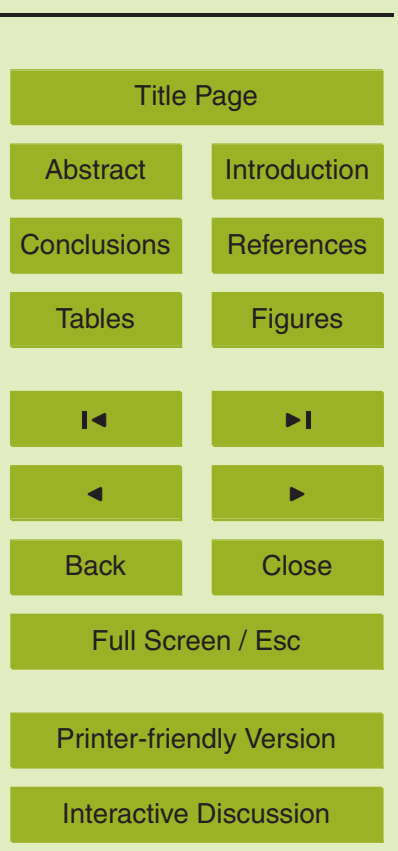

Interactive Discussion 
Kröger, N. and Poulsen, N.: Diatoms-from cell wall biogenesis to nanotechnology., Annu. Rev. Genet., 42, 83-107, 2008.

Lewin, J. C.: Silicon metabolism in diatoms, J. Gen. Physiol., 39, 1-10, 1955.

Lippemeier, S., Hartig, P., and Colijn, F.: Direct impact of silicate on the photosynthetic perfor-

5 mance of the diatom Thalassiosira weissflogii assessed by on- and off-line pam fluorescence measurements, J. Plankton Res., 21, 269-283, 1999.

Lippemeier, S., Hintze, R. H., Vanselow, K., Hartig, P., and Colijn, F.: In-line recording of pam fluorescence of phytoplankton cultures as a new tool for studying effects of fluctuating nutrient supply on photosynthesis, Eur. J. Phycol., 36, 89-100, 2001.

10 Mague, T. H., Friberg, E., Hugues, D. J., and Morris, I.: Extracellular release of carbon by marine phytoplankton; a physiological approach, Limnol. Oceanogr., 25, 262-279, 1980.

Martin-Jézéquel, V., Hildebrand, M., and Brzezinski, M. A.: Silicon metabolism in diatoms: implications for growth, J. Phycol., 36, 821-840, 2000.

Mayzaud, P., Claustre, H., and Augier, P.: Effect of variable nutrient supply on fatty acid compo15 sition of phytoplankton grown in an enclosed experimental ecosystem, Mar. Ecol.-Prog. Ser., 60, 123-140, 1990.

Moriceau, B., Goutx, M., Guigue, C., Lee, C., Armstrong, R., Duflos, M., Tamburini, C., Charrière, B., and Ragueneau, O.: Si-C interactions during degradation of the diatom skeletonema marinoi, Deep-Sea Res. Pt. II, 56, 1381-1395, 2009.

20 Nelson, D. M., Tréguer, P., Brzezinski, M. A., Leynaert, A., and Quéguiner, B.: Production and dissolution of biogenic silica in the ocean: revised global estimates, comparison with regional data and relationship to biogenic sedimentation, Global Biogeochem. Cy., 9, 359-372, 1995.

Nelson, D. M. and Dortch, Q.: Silicic acid depletion and silicon limitation in the plume of the Mississippi River: evidence from kinetic studies in spring and summer, Mar. Ecol.-Prog. Ser., 25 136, 163-178, 1996.

Osborne, B. A. and Geider, R. J.: Effect of nitrate-nitrogen limitation on photosynthesis of the diatom phaeodactylum tricornutum bohlin (bacillariophyceae), Plant Cell Environ., 9, 617625, 1986.

Parkinson, J., Brechet, Y., and Gordon, R.: Centric diatom morphogenesis: a model based on a dla algorithm investigating the potential role of microtubules, Biochim. Biophys. Acta, 1452, 89-102, 1999.

Passow, U.: Production of transparent exopolymer particles (tep) by phyto- and bacterioplankton, Mar. Ecol.-Prog. Ser., 236, 1-12, 2002.

\section{Impact of nutrient availability on frustule composition}

C. Soler et al.

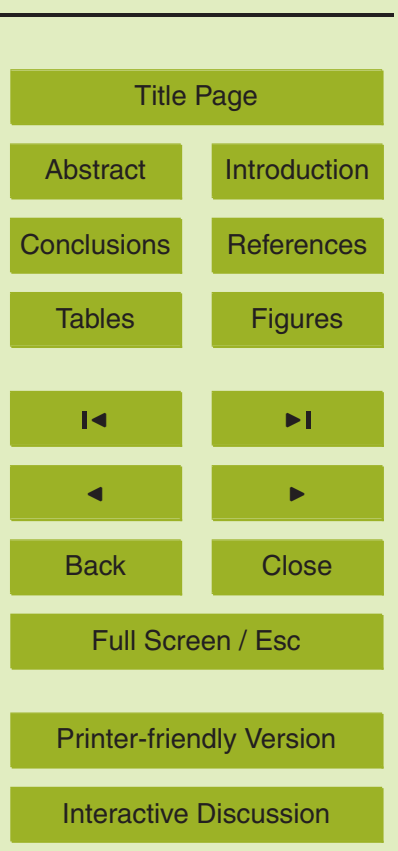

Interactive Discussion 
Poulsen, N., Sumper, M., and Kröger, N.: Biosilica formation in diatoms: characterization of native silaffin-2 and its role in silica morphogenesis, P. Natl. Acad. Sci. USA, 100, 1207512080, 2003.

Poulsen, N. and Kröger, N.: Silica morphogenesis by alternative processing of silaffins in the diatom Thalassiosira pseudonana, J. Biol. Chem., 279, 42993-42999, 2004.

Ragueneau, O., De Blas Varela, E., Tréguer, P., Quéguiner, B., and Del Amo, Y.: Phytoplankton dynamics in relation to the biogeochemical cycle of silicon in a coastal ecosystem of Western Europe, Mar. Ecol.-Prog. Ser., 106, 157-172, 1994.

Ragueneau, O. and Treguer, P.: Determination of biogenic silica in coastal waters: applicability and limits of alkaline digestion method, Mar. Chem., 45, 43-51, 1994.

Ragueneau, O., Schultes, S., Bidle, K., Claquin, P., and Moriceau, B.: Si and C interactions in the world ocean: importance of ecological processes and implications for the role of diatoms in the biological pump, Global Biogeochem. Cy., 20, GB4S02, doi:10.1029/2006GB002688, 2006.

Reynolds, R. A., Stramski, D., and Kiefer, D. A.: The effect of nitrogen limitation on the absorption and scattering properties of the marine diatom Thalassiosira pseudonana, Limnol. Oceanogr., 42, 881-892, 1997.

Round, F. E., Crawford, R. M., and Mann, D. G.: The Diatoms: Biology and Morphology of the Genera, Cambridge University Press, Berlin, 1990.

20 Schreiber, U., Schliwa, U., and Bilger, W.: Continuous recording of photochemical and nonphotochemical chlorophyll fluorescence quenching with a new type of modulation fluorometer, Photosynth. Res., 10, 51-62, 1986.

Shifrin, N. S. and Chisholm, S. W.: Phytoplankton lipids: interspecifix differences and effects of nitrate, silicate and light-dark cycles, J. Phycol., 17, 374-384, 1981.

25 Smetacek, V.: Diatoms and the ocean carbon cycle, Protist, 150, 25-32, 1999.

Soler, C., Moriceau, B., Amiel, C., Goutx, M., Ragueneau, O., and Claquin, P.: Exploring the composition of cleaned diatom frustules by Fourier Transform Infrared Spectroscopy, J. Phycol., in review, 2010.

Staats, N., Stal, L. J., and Mur, L. R.: Exopolysaccharide production by the epipelic diatom 30 cylindrotheca closterium: effects of nutrient conditions, J. Exp. Mar. Biol. Ecol., 249, 13-27, 2000.

Sullivan, C. W.: Diatom mineralization of silicic acid. I. Si $(\mathrm{OH})_{4}$ transport characteristics in Navicula pelliulosa, J. Phycol., 12, 390-396, 1976.

\section{BGD}

7, 5953-5995, 2010

\section{Impact of nutrient availability on frustule composition}

C. Soler et al.

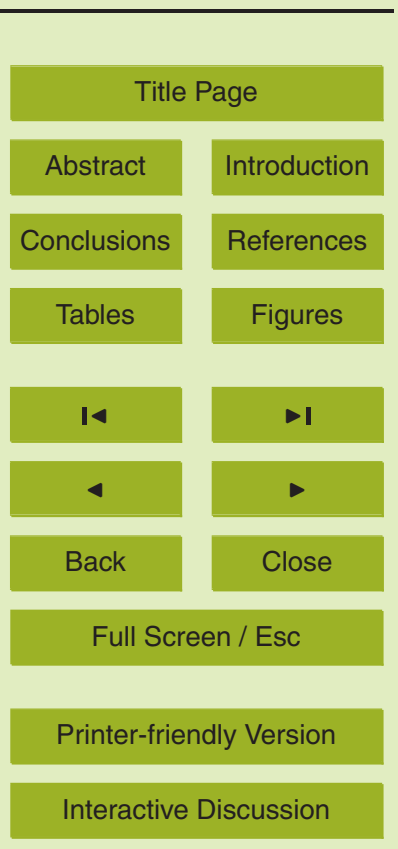


Sumper, M.: A phase separation model for the nanopatterning of diatom biosilica, Science, 295, 2430-2433, 2002.

Sumper, M. and Kröger, N.: Silica formation in diatoms: the function of long-chain polyamines and silaffins, J. Mater. Chem., 14, 2059-2065, 2004.

5 Swift, D. M. and Wheeler, A. P.: Evidence of an organic matrix from diatom biosilica, J. Phycol., 28, 202-209, 1992.

Tang, K. W. and Dam, H. G.: Phytoplankton inhibition of copepod egg hatching: test of an exudate hypothesis, Mar. Ecol.-Prog. Ser., 209, 197-202, 2001.

Theodorou, M. E., Elrifi, I. R., Turpin, D. H., and Plaxton, W. C.: Effects of phosphorus limitation on respiratory metabolism in the green alga selenastrum minutum, Plant Physiol., 95, 10891095, 1991.

Thornton, D. C. O.: Diatom aggregation in the sea: mechanisms and ecological implications, Eur. J. Phycol., 37, 149-161, 2002.

Tréguer, P. and Pondaven, P.: Global change - silica control of carbon dioxide, Nature, 406, 15 358-359, 2000.

Underwood, G. J. C., Boulcott, M., Raines, C. A., and Waldron, K.: Environmental effects on exopolymer production by marine benthic diatoms: dynamics, changes in composition, and pathways of production, J. Phycol., 40, 293-304, 2004.

Vartanian, M., Descles, J., Quinet, M., Douady, S., and Lopez, P. J.: Plasticity and robustness of pattern formation in the model diatom phaeodactylum tricornutum, New Phytol., 182, 429442, doi:10.1111/j.1469-8137.2009.02769.x, 2009.

ZoBell, C. E.: Studies on marine bacteria. I. The cultural requirement of heterotrophic aerobes, J. Mar. Res., 4, 42-75, 1941

Zurzolo, C. and Bowler, C.: Exploring bioinorganic pattern formation in diatoms. A story of polarized trafficking, Plant Physiol., 127, 1339-1345, 2001.

\section{BGD}

7, 5953-5995, 2010

\section{Impact of nutrient availability on \\ frustule composition}

C. Soler et al.

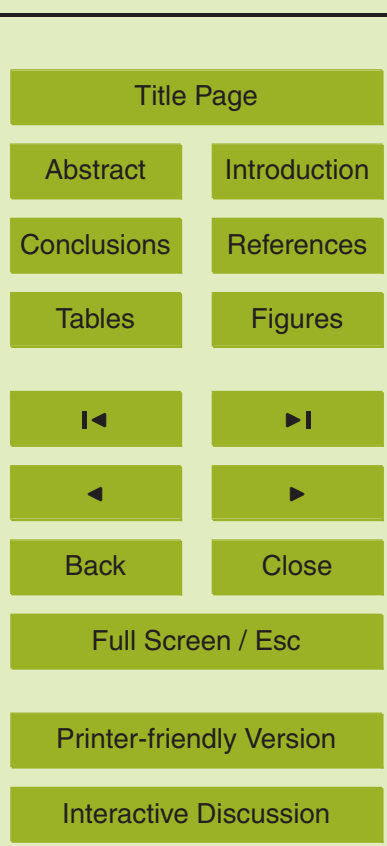


BGD

7, 5953-5995, 2010

\section{Impact of nutrient} availability on

frustule composition

C. Soler et al. in $\mu \mathrm{mol}^{-1}(\mathrm{mg} \mathrm{Chl}-a)^{-1} \mathrm{~s}^{-1} ; \alpha$ in $\left.\mathrm{mmol} \mathrm{e}^{-1}(\mathrm{mg} \mathrm{Chl}-a)^{-1}(\mu \mathrm{mol} \text { photons })^{-1} \mathrm{~m}^{2}\right)$.

\begin{tabular}{llllllllll}
\hline & Culture & $F_{\mathrm{v}} / F_{\mathrm{m}}$ & $R^{2}$ & $\mathrm{ETR} \max$ & $\mathrm{SD}$ & $\alpha$ & $\mathrm{SD}$ & $\omega$ & $\mathrm{SD}$ \\
\hline $\mathrm{T} 1$ & Control & 0.61 & 1.00 & 2.932 & 0.322 & 4.562 & 0.127 & 1.410 & 0.007 \\
& $\mathrm{NO}_{3}$ st & 0.63 & 1.00 & 0.952 & 0.044 & 2.708 & 0.053 & 1.863 & 0.002 \\
& $\mathrm{Si}(\mathrm{OH})_{4}$ st & 0.61 & 0.99 & 0.580 & 0.078 & 1.543 & 0.087 & 1.031 & 0.097 \\
& $\mathrm{PO}_{4}$ st & 0.63 & 0.99 & 0.166 & 0.008 & 0.432 & 0.009 & 1.038 & 0.036 \\
$\mathrm{~T} 7$ & & & & & & & & & \\
& $\mathrm{NO}_{3}$ st & 0.61 & 1.00 & 0.377 & 0.06 & 1.538 & 0.010 & $2.630 \mathrm{E}-09$ & $0.054 \mathrm{E}-09$ \\
& ${\mathrm{Si}(\mathrm{OH})_{4} \text { st }}$ & 0.56 & 1.00 & 0.352 & 0.055 & 1.409 & 0.010 & 0.849 & 0.154 \\
& $\mathrm{PO}_{4}$ st & 0.30 & 0.99 & 0.013 & 0.007 & 0.111 & 0.003 & - & - \\
$\mathrm{T} 12$ & $\mathrm{NO}_{3}$ st & 0.50 & 1.00 & 0.238 & 0.014 & 1.074 & 0.037 & 0.805 & 0.062 \\
& $\mathrm{Si}(\mathrm{OH})_{4}$ st & 0.44 & 1.00 & 0.200 & 0.020 & 0.747 & 0.038 & 0.786 & 0.094 \\
\hline
\end{tabular}




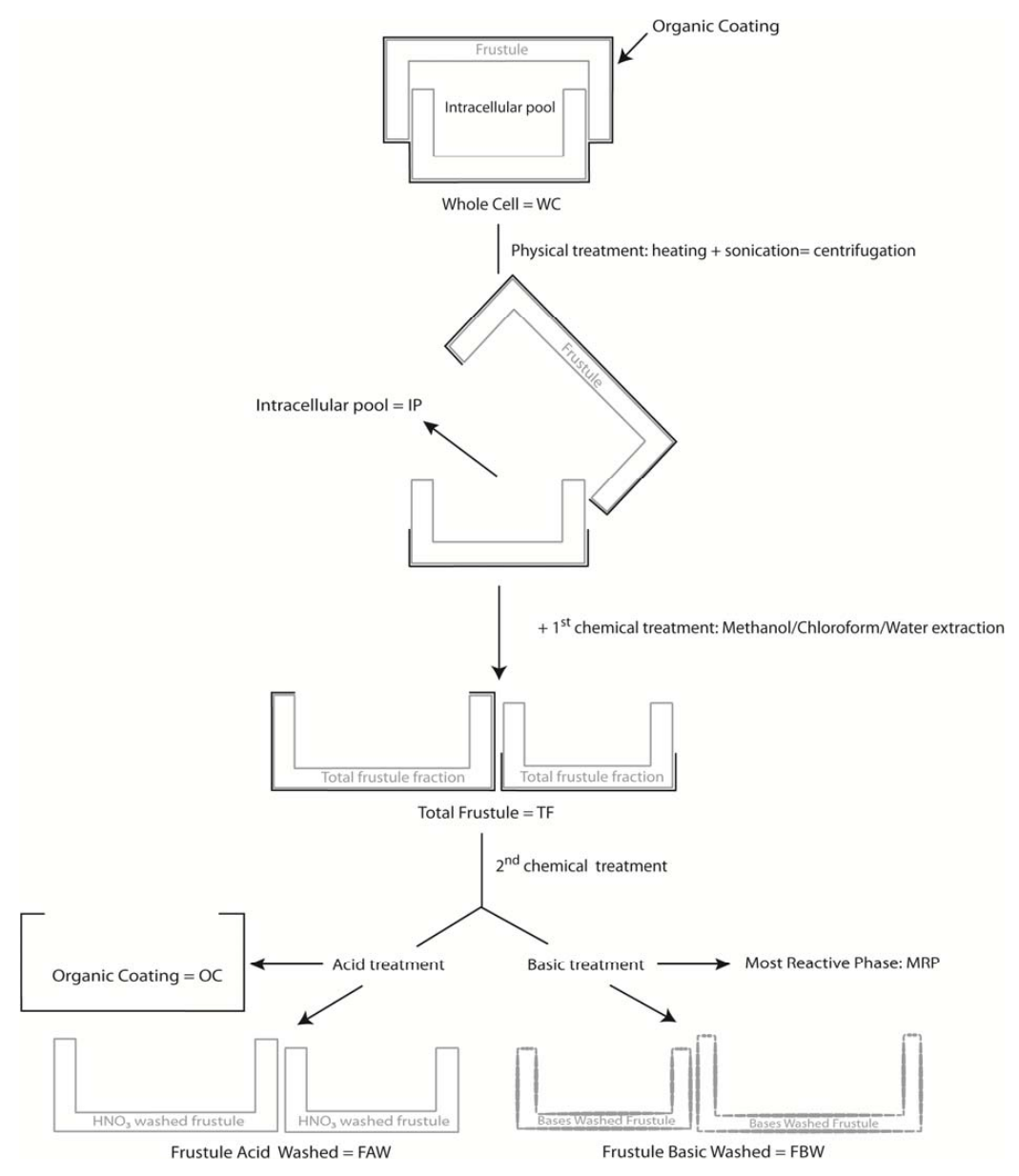

BGD

7, 5953-5995, 2010

\section{Impact of nutrient availability on frustule composition}

C. Soler et al.

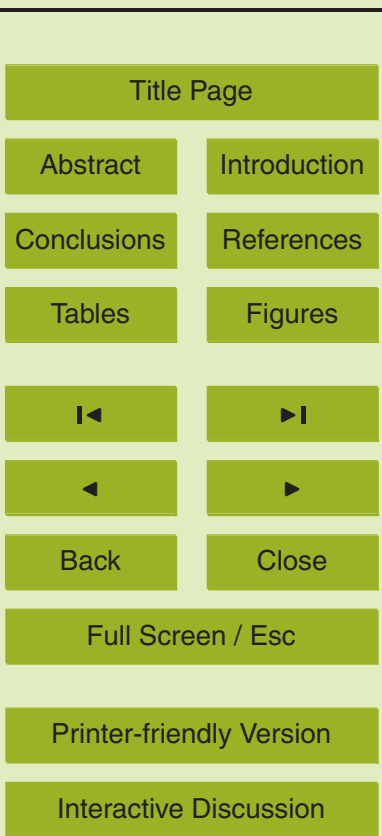

Fig. 1. Fractionation of diatom and its frustule. 
BGD

$7,5953-5995,2010$
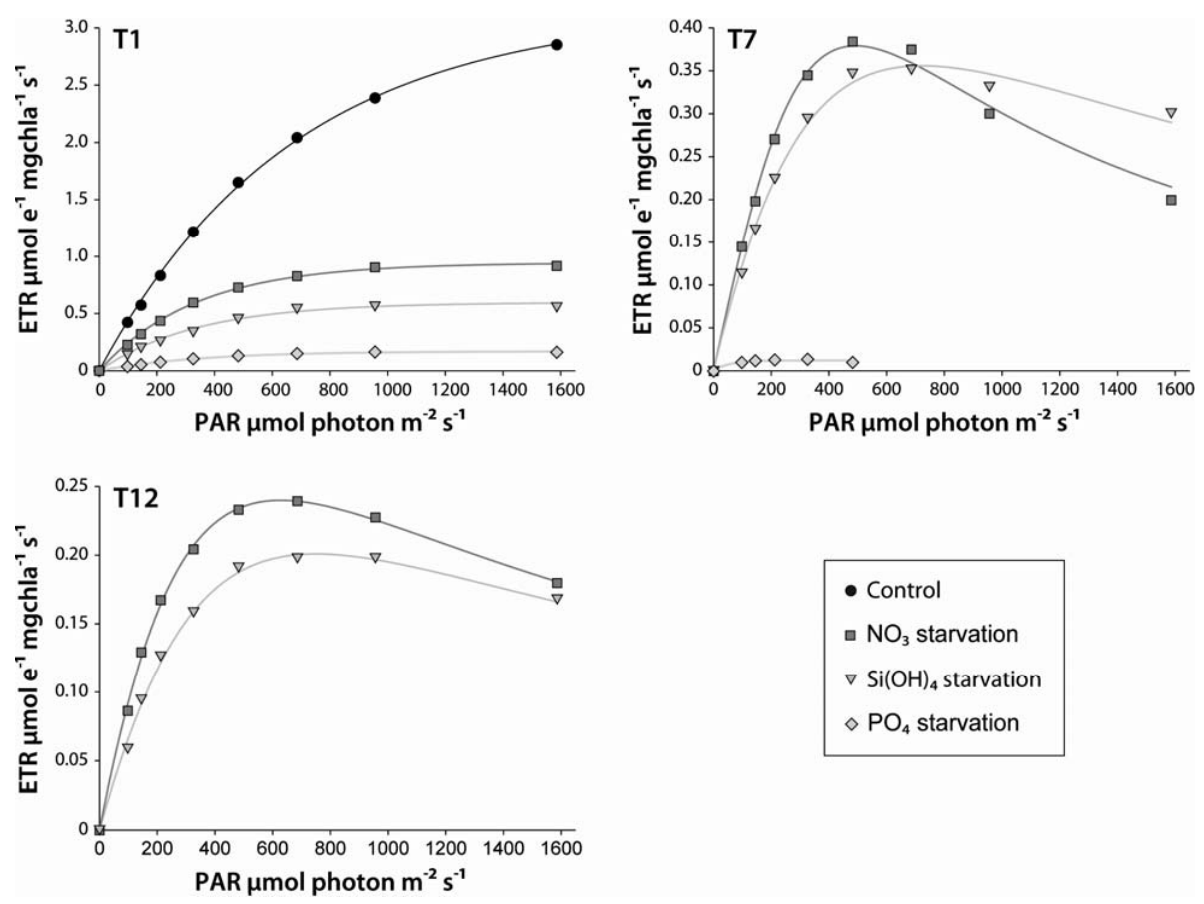

$$
\begin{aligned}
& \text { - Control } \\
& \text { - } \mathrm{NO}_{3} \text { starvation } \\
& \nabla \mathrm{Si}(\mathrm{OH})_{4} \text { starvation } \\
& \diamond \mathrm{PO}_{4} \text { starvation }
\end{aligned}
$$

Fig. 2. Photosynthesis versus irradiance curves obtained after fitting the data with Eilers and Peeters model (1988) for Thalassiosira weissflogii culture grown under various nutrient starvations.

\section{Impact of nutrient availability on \\ frustule composition}

C. Soler et al.

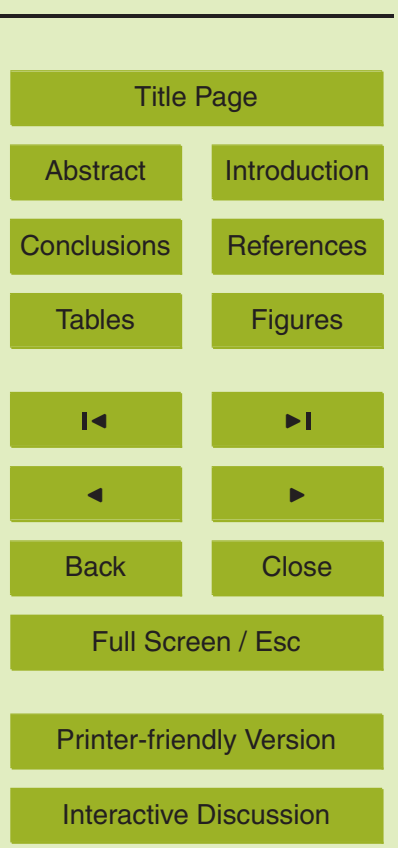




\section{BGD}

$7,5953-5995,2010$

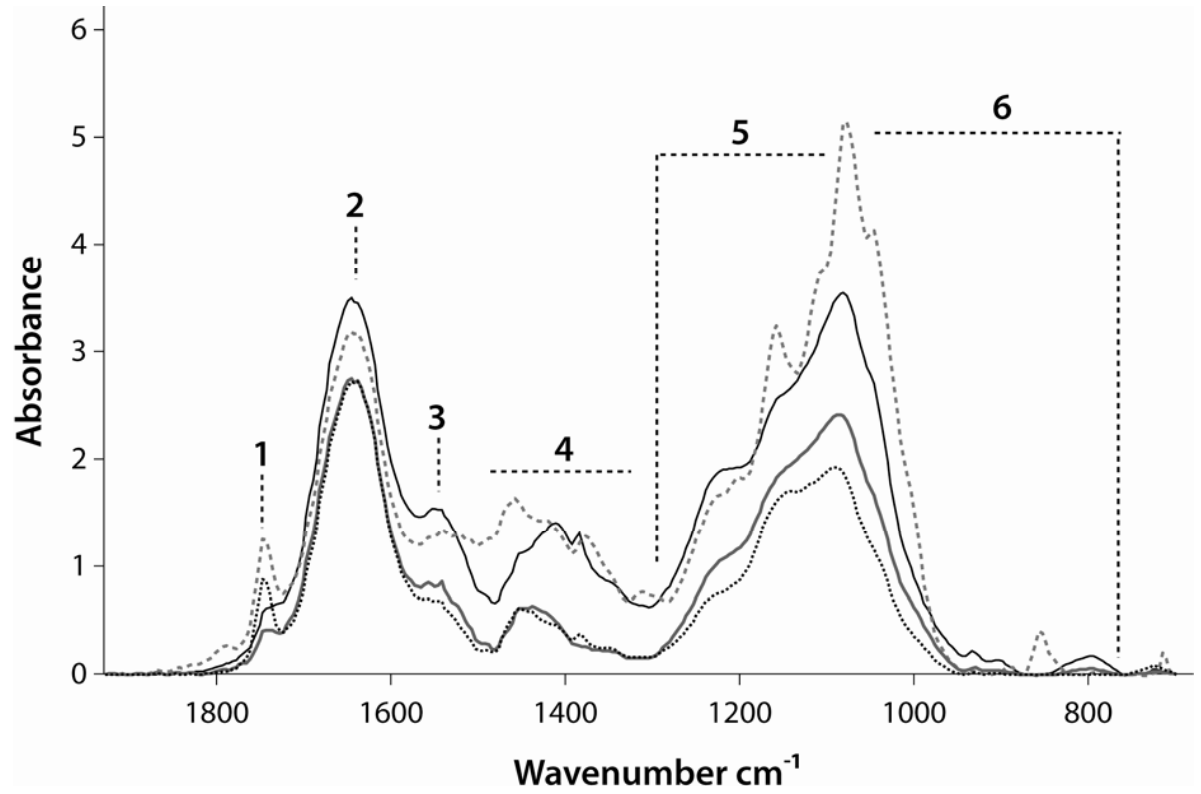

Fig. 3. FTIR spectra of Thalassiosira weissflogii whole cells grown under various nutrient conditions: control (black solid line), $\mathrm{PO}_{4}$ starvation (grey dashed line), $\mathrm{NO}_{3}$ starvation (grey solid line) and $\mathrm{Si}(\mathrm{OH})_{4}$ starvation (grey dotted line).

\section{Impact of nutrient availability on \\ frustule composition}

C. Soler et al.

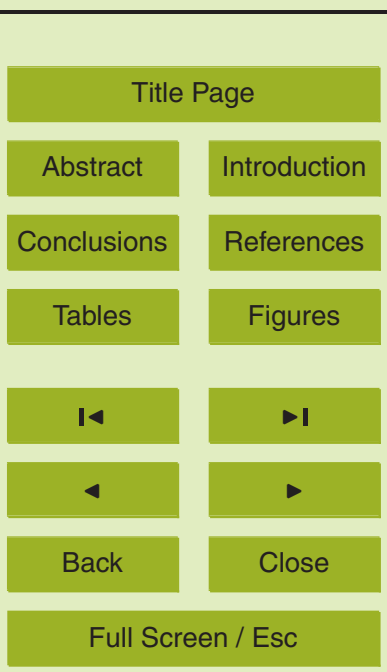

Printer-friendly Version

Interactive Discussion 

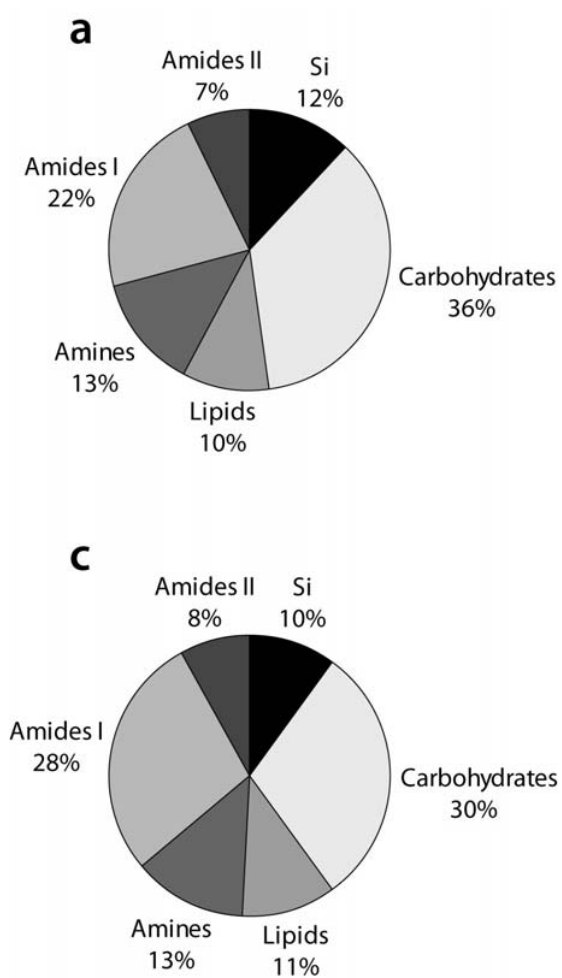

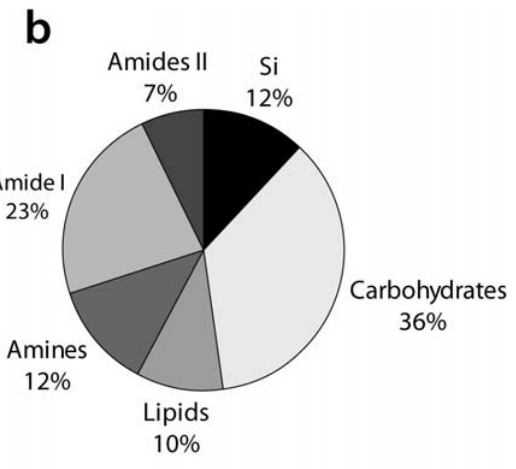

d

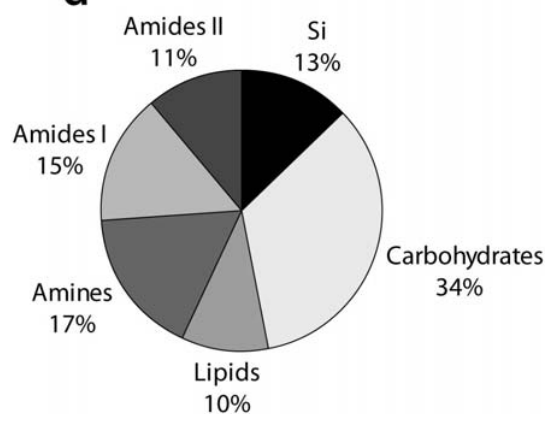

BGD

7, 5953-5995, 2010

\section{Impact of nutrient availability on frustule composition}

C. Soler et al.

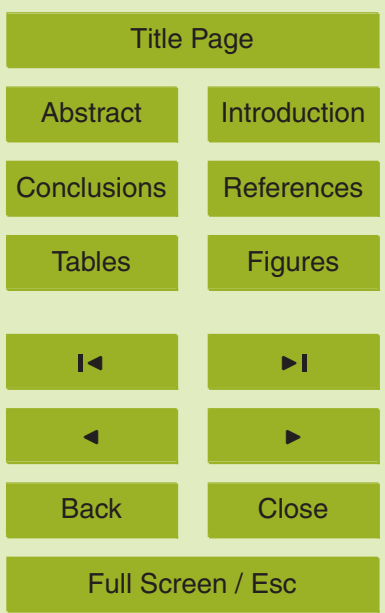

Printer-friendly Version

Interactive Discussion 

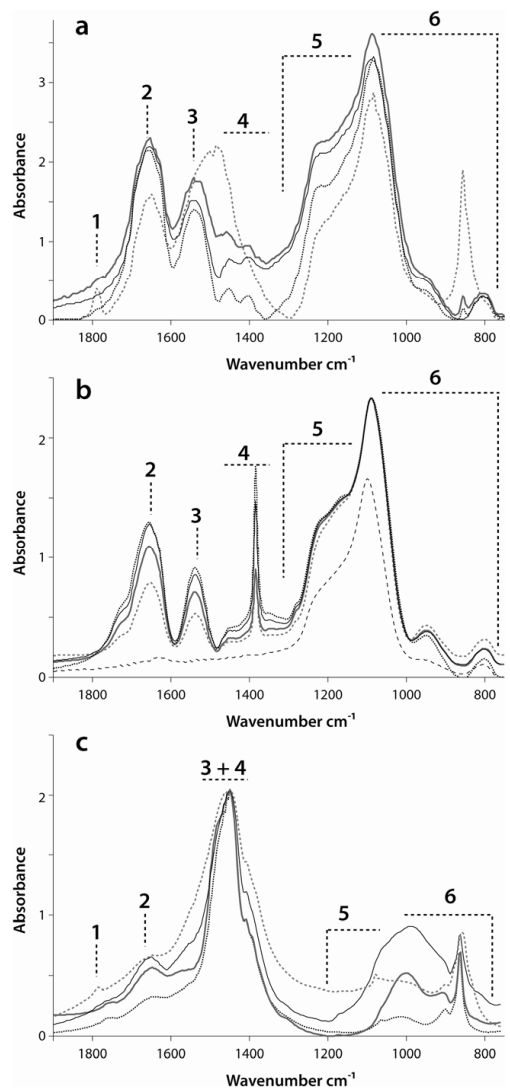

BGD

7, 5953-5995, 2010

Impact of nutrient availability on frustule composition

C. Soler et al.

Title Page

Abstract

Introduction

Conclusions

References

Tables

Figures

14

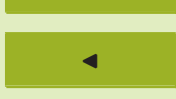

Back

Close

Full Screen / Esc

Fig. 5. FTIR spectra of the different frustule fractions isolated from Thalassiosira weissflogii cells grown under various nutrient conditions: control (black solid line), $\mathrm{PO}_{4}$ starvation (grey dashed line), $\mathrm{NO}_{3}$ starvation (grey solid line) and $\mathrm{Si}(\mathrm{OH})_{4}$ starvation (grey dotted line). (a) Total frustule fraction (TF); (b) acid washed frustule fraction (FAW), the larger dashed line correspond to the diatomite spectra; (c) basic washed frustule fraction (FBW). 


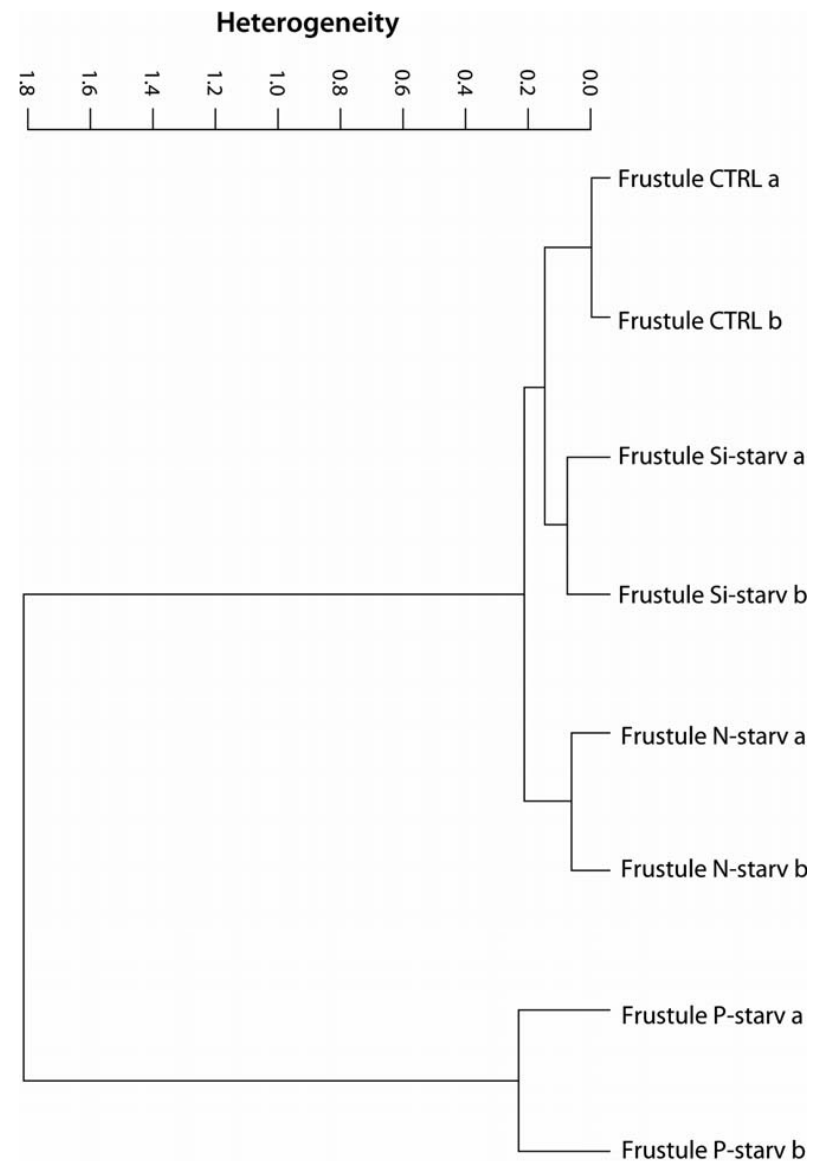

BGD

7, 5953-5995, 2010

\section{Impact of nutrient availability on frustule composition}

C. Soler et al.

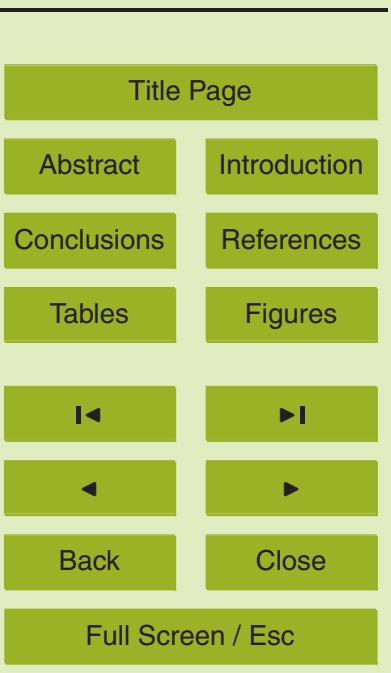

Printer-friendly Version

Fig. 6. Cluster analysis of the FTIR spectra of total frustule fractions isolated from Thalassiosira weissflogii diatom cells grown under nutrient starvations constructed using Ward analysis in the frequency range $2200-800 \mathrm{~cm}^{-1}$. 
BGD

$7,5953-5995,2010$
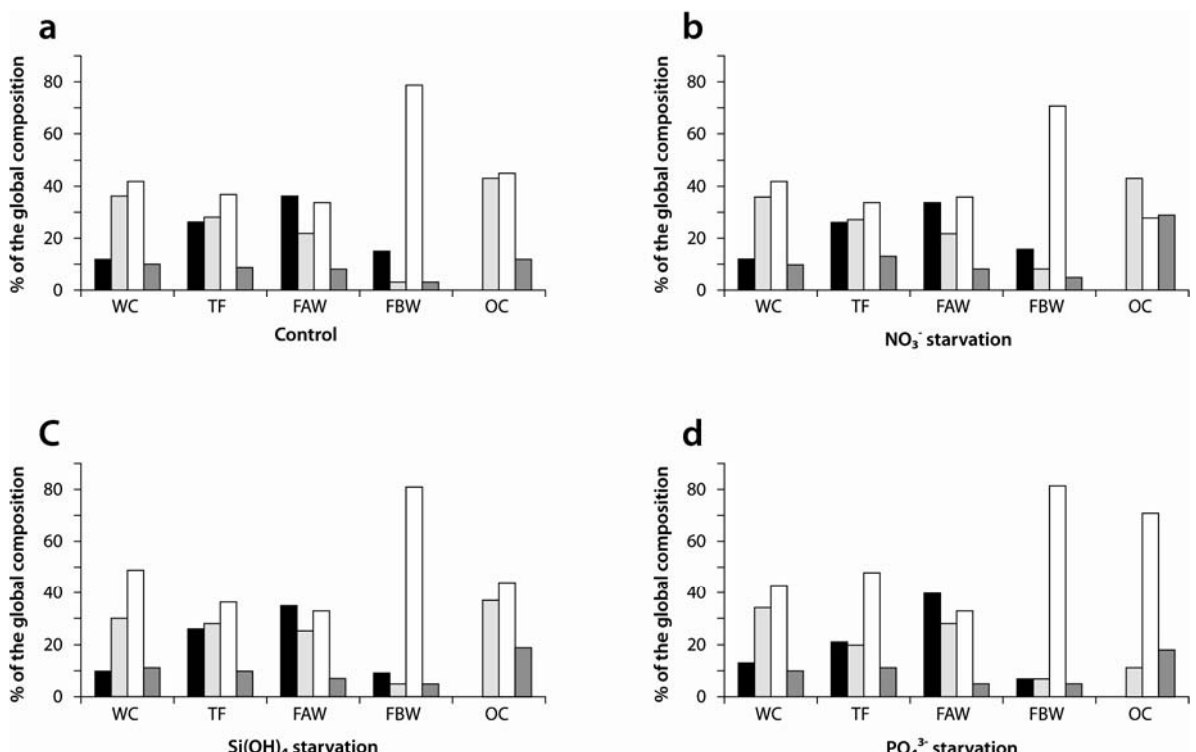

Biochemical composition of T. weissflogii

- $\mathrm{bSiO}_{2} \quad \square$ Carbohydrate $\square$ Totalprotein $\square$ Lipid

Fig. 7. Relative contribution of the main biochemical pools to the composition of Thalassiosira weissflogii whole cells and frustule fractions in (a) control conditions; (b) $\mathrm{NO}_{3}$ starved; (c) $\mathrm{Si}(\mathrm{OH})_{4}$ starved and (d) $\mathrm{PO}_{4}$ starved conditions. (WC: whole cells; TF: total frustule; FAW: acid washed frustule; FBW: basic washed frustule and OC: organic coating).

\section{Impact of nutrient availability on \\ frustule composition}

C. Soler et al.

\section{Title Page}

Abstract Introduction

Conclusions

References

Tables

Figures

14

$>$

4

Back

Close

\section{Full Screen / Esc}

Printer-friendly Version

Interactive Discussion 


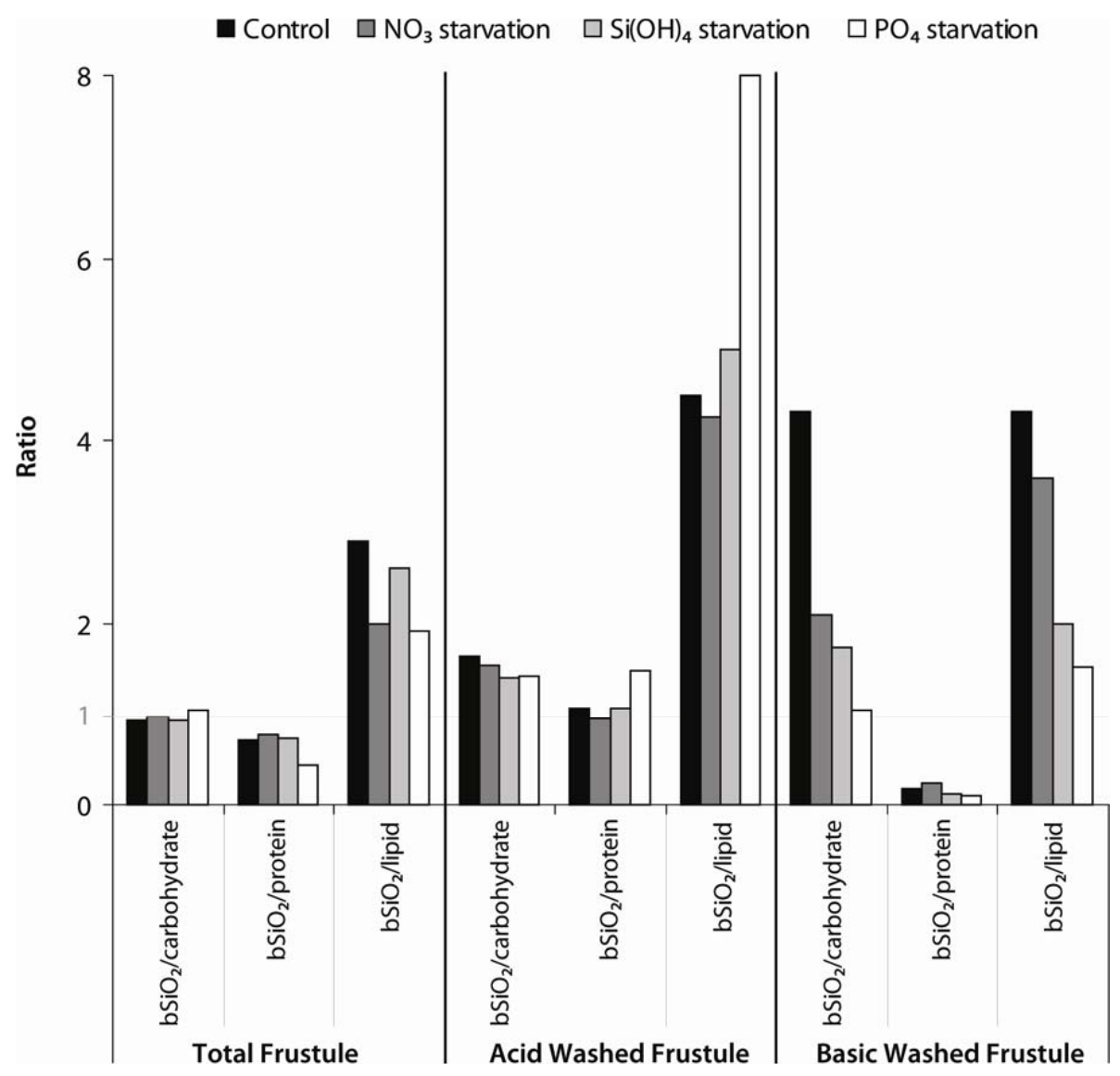

BGD

7, 5953-5995, 2010

Impact of nutrient availability on frustule composition

C. Soler et al.

Title Page

Abstract

Introduction

Conclusions

References

Tables

Figures

$\mathbf{I}$

4

Back

\section{Full Screen / Esc}

Printer-friendly Version

Interactive Discussion

Fig. 8. Comparison of $\mathrm{bSiO}_{2}$ contribution versus main biochemical pools contribution for the different frustule fractions extracted from $T$. weissflogii cells grown under various growth conditions (control, $\mathrm{NO}_{3}$ starvation, $\mathrm{Si}(\mathrm{OH})_{4}$ starvation, $\mathrm{PO}_{4}$ starvation).

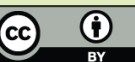

